\title{
PLURALISMO JURÍDICO: O PALIMPSESTO POLÍTICO E JURÍDICO EM MOÇAMBIQUE E DIREITO DE PASÁRGADA NO BRASIL
}

\author{
LEGAL PLURALISM: THE POLITICAL AND LEGAL PALIMPSEST IN MOZAMBIQUE \\ AND THE PASÁRGADA LAW IN BRAZIL
}

Custódio Vique Jossia Júnior*

\begin{abstract}
Sumário: Introdução. 1. Do Monismo Jurídico ao Pluralismo Jurídico: Crise e Emergência do Pensamento Jurídico Moderno. 1.1. Monismos Jurídicos. 1.2. Pluralismo: conceito e origem. 2. Pluralismo Jurídico em Moçambique. 2.1. O Pluralismo Jurídico Moçambicano: o palimpsesto de políticas e culturas jurídicas. 2.1.1. O Estado Colonial. 2.1.2. Monismos Estadualista no período pós Independência: Estado, o único criador do direito. 2.2. Tratamentos constitucionais do pluralismo jurídico em Moçambique. 2.3. Estudos de caso. Justiças cruzadas no bairro Jorge Dimitrov. 3. Pluralismo Jurídico no Brasil. 3.1. Pluralismo jurídico e direito alternativo no Brasil. 3.2. Direito de Pasárgada. 3.3. Do direito de pasárgada à manifestação legal do pluralismo no Brasil: o exemplo dos juizados especiais civil. Considerações Finais. Referências.
\end{abstract}

Resumo: A proposta de trabalho é fazer uma reflexão paralela a respeito da construção do pluralismo jurídico em Moçambique e no Brasil, com ênfase na teoria do estudo feito por Boaventura de Sousa Santos (o palimpsesto político, jurídico e direito de pasárgada). A ideia de pluralismo jurídico é decorrente da existência de dois ou mais sistemas jurídicos, dotados de eficácia, concomitantemente em um mesmo ambiente espaço-temporal. Em Moçambique estudos sobre a matéria reconheceram a presença de direito fora do Estado, onde era fácil identificar a presença de diferentes ordens jurídicas: de um lado, o direito europeu; do outro,

\footnotetext{
* Universidade Federal de Pernambuco
} 
os direitos costumeiros dos povos nativos. Já no contexto histórico do surgimento de pluralismo jurídico no Brasil, este surge com o Direito de Pasárgada na década de 1930 na cidade do Rio de Janeiro.

Palavras-chave: Pluralismo Jurídico; Monismo; Palimpsesto; Pasárgada.

Abstract: The work proposal is to reflect about the parallel construction of legal pluralism in Mozambique and in Brazil, with emphasis on the theory of the study made by Boaventura de Sousa Santos (the political and legal Palimpsest and the Pasárgada law). The idea of legal pluralism follows the existence of two or more legal systems, endowed with effectiveness, concurrently in the same space-time environment. In Mozambique studies on the subject recognized the presence of law outside the state where it was easy to identify the presence of different legal systems: on the one hand, European law, and on the other, customary rights of indigenous peoples. In the historical context of the emergence of legal pluralism in Brazil, this arises with the Law of Pasárgada in 1930 in the city of Rio de Janeiro.

Keywords: Legal Pluralism, Monism; Palimpsest; Pasárgada.

\section{INTRODUÇÃO}

O objeto deste trabalho é fazer uma reflexão paralela a respeito da construção do Pluralismo jurídico em Moçambique e no Brasil, com ênfase na teoria no estudo feita por Boaventura de Sousa Santos (o palimpsesto ${ }^{1}$ político, jurídico e direito de pasárgada).

O objetivo principal é discutir a forma como se apresenta e o Pluralismo Jurídico em Moçambique e no Brasil (Teoria Crítica), problematizando-os e mostrando a diferença na

\footnotetext{
${ }^{1}$ Boaventura de Sousa Santos no estudo que fez sobre o pluralismo jurídico em Moçambique serviu-se de uma metáfora para pretender mostrar como as diferentes culturas políticas e jurídicas que perpassaram o Estado Moçambicano ao longo da sua história continuam a cruzar-se na realidade política e judiciária moçambicana, apelidou esse fenômeno de palimpsesto de políticas e culturas jurídicas. Um palimpsesto é um pergaminho ou
} 
postura de aplicação (se é que as normas postas estão de fato tendo aplicabilidade) desse direito e a sua evolução histórica no caso de Moçambique.

Fundamenta-se este trabalho nos estudos realizados por Boaventura de Sousa Santos, a fim de salientar que o direito emerge da sociedade e para trazer a crítica do direito positivado.

O motivo para a realização deste estudo foi justamente a possibilidade de discutir um tema que está em evidencia no direito de dois países com alguma semelhança cultural, visto que ambos foram colônias portuguesas. Por isso, é de suma importância o debate acerca desse assunto para que mais pessoas tomem conhecimento de como é tratado o direito no Brasil e em Moçambique tomando ciência também da importância do direito alternativo. Dentre as preocupações mais significativas é preciso salientar: o que é o direito alternativo; quais as posturas de aplicação do direito alternativo em Moçambique e no Brasil.

Para desenvolver o trabalho necessário se fez realizar um estudo sobre o pluralismo jurídico em Moçambique e no Brasil, a partir de uma revisão da literatura dando ênfase às obras de Boaventura de Sousa Santos. No caso de Moçambique foi explorada também alguma legislação atual (Constituição da República de Moçambique de 2004) e colonial e feita abordagem do estudo de Sara Araújo em Moçambique. Portanto, para esse efeito o texto divide-se em três pontos:

No primeiro, analiso os conceitos de monismo jurídico e de pluralismo jurídico e interlegalidade;

No segundo, de pluralismo jurídico em Moçambique (o palimpsesto político, jurídico) onde se faz uma resenha histórica do surgimento do pluralismo jurídico em Moçambique, apresento algumas das principais linhas de debate que têm alimentado a discussão sobre estratégias que têm vindo a ser usadas pelo Estado para integrar ou excluir pluralidade e também o tratamento constitucional que foi dado ao pluralismo jurídico em Moçambique e em alguns países do mundo; o capítulo encerra com uma apresentação sintética de alguns resultados de um trabalho de campo realizado no bairro Jorge Dimitrov, em Maputo, sobre esta temática.

Finalmente no terceiro ponto, centro-me no contexto histórico do pluralismo no 
Brasil, onde se tratará de forma sucinta a resolução de conflitos no direito de pasárgada, bem como as relações entre o estado brasileiro e seu direito com a forma de organização social e jurídica, o caso dos Juizados Especiais de Pequenas Causas.

\section{DO MONISMO JURÍdico AO PLURALISMO JURÍdico: CRISE E EMERGÊNCIA DO PENSAMENTO JURÍDICO MODERNO}

\subsection{Monismos jurídicos}

O monismo é uma doutrina que floresceu no modernismo, portanto, a partir do século XVII e XVII, cujo pressuposto fundamental é o Estado como único e universal criador da norma jurídica, aqui não se admite a ideia de qualquer outra jurídica que não a emanada do Estado. Wolkmer estudou a correte monista e afirmou que "tal concepção atribuiu ao Estado Moderno o monopólio exclusivo da produção das normas jurídicas, ou seja, o Estado é o único agente legitimado capaz de criar legalidade para enquadrar as formas de relação social que vão se impondo"2.

Sendo que o Estado é a fonte única do Direito, uma vez que somente ele pode dar vida ao Direito por meio da sua força coativa. Logo, para esta teoria só as normas emanadas do Estado é que se consideram Direito. O Estado é entendido como sendo o "centro único do poder e detentor do monopólio de produção de normas jurídicas"3.

Neste contexto, como ensina Carvalho, no monismo "a lei se vale pelo simples fato de ser lei, de modo que sua legitimidade advém da mera observância dos procedimentos previamente estabelecidos, isto é, das normas que regulam o processo legislativo"4.

Assim, Arnaldo Vasconcelos “entende que o monismo jurídico foi responsável pela crise que culminou com o descrédito do Positivismo, por uma razão de ordem político-ideológico: faltavam condições ao Positivismo monista para legitimar a ordem jurídica, já que, para a doutrina monista, não havia espaço para as questões de justiça e de legitimidade" ${ }^{\text {. }}$. Em contraposição ao monismo, surge a teoria do pluralismo jurídico.

\footnotetext{
${ }^{2}$ WOLKMER, Antonio Carlos. Pluralismo Jurídico: fundamentos de uma nova cultura no direito. 3. ed. São Paulo: Alfa Omega, 2001, p. 46

${ }^{3}$ CARVALHO, Lucas Borges de. Caminhos (e descaminhos) do pluralismo jurídico no Brasil. In: WOLKMER, Antonio Carlos; VERNAS NETO, Francisco Q.; LIXA, Ivone M. (Orgs.). Pluralismo jurídico: os novos caminhos da contemporaneidade. São Paulo: Saraiva, 2010, p. 14.

${ }^{4}$ Ibid., p. 13-36.

${ }^{5}$ VASCONCELOS, Arnaldo. Teoria da Norma Jurídica. 6. ed. São Paulo: Malheiros, 2006, p. 257-258.
} 


\subsection{Pluralismo: conceito e origem}

Existe uma grande indefinição acerca do conceito de pluralismo jurídico. O dissenso se dá, inicialmente, em face de um problema conceitual fundamental: a dificuldade de se definir o que é direito para fins de pluralismo jurídico e, portanto, de quais regras devem ser consideradas no espectro analisado como sendo "Direito".

Boaventura de Sousa Santos identifica duas origens possíveis para o surgimento do pluralismo: uma origem colonial e outra não colonial. ${ }^{7}$ No primeiro caso, o pluralismo desenvolveu-se em países que foram dominados econômica e politicamente e onde, por isso, vigorou o ordenamento jurídico do estado colonizador paralelamente ao direito tradicional (caso de Moçambique $\left.{ }^{8}\right) .{ }^{9}$

No segundo caso, o autor identifica três situações diferenciadas: o caso dos países com cultura e tradição jurídicas próprias, mas que adotaram o direito europeu como forma de modernização e de consolidação do poder do Estado (Turquia, Tailândia e Etiópia), e que não eliminaram, no plano sociológico, o direito tradicional; o caso dos países que, após passarem por uma revolução social, continuaram mantendo o direito tradicional, muito embora se conflitasse com o direito revolucionário (Repúblicas da Ásia Central, de tradição islâmica, incorporadas pela antiga URSS); e, por último, os casos da populações indígenas ou nativas que foram dominadas por uma metrópole, mas tiverem permissão, implícita ou explícita para, em certos domínios, manterem seus direito tradicional (populações indígenas da América do Norte, da Oceania etc. $)^{10}$.

Na Europa, o pluralismo jurídico teve sua origem no contexto da antiguidade clássica, onde existia uma grande predominância de normais legais de caráter espontâneo e comunitário, elaboradas pela população sem controlo estatal. Destacam-se aqui as sociedades que se encontravam sob domínio do império romano, onde a principal característica da

\footnotetext{
${ }^{6}$ TAMANAHA, Brian. Understanding Legal Pluralism: Past to Present, Local to Global. Sidney Law Review, v. 30, n. 3, September 2008, p. 376.

${ }^{7}$ SANTOS. Boaventura de Sousa. O discurso e o poder. Ensaios sobre a sociologia retórica jurídica. Porto Alegre: SAFE, 1988, p. 73-75.

${ }^{8}$ Grifos nosso.

${ }^{9}$ SANTOS. Boaventura de Sousa. Op. cit., p. 73-75.

${ }^{10}$ Loc. cit.
} 
dominação romana era tolerância com os povos que dominavam.

Nesse aspecto, os romanos eram mais tolerantes e não tinham o hábito de não impor rigidamente suas leis aos povos que conquistava, permitindo a continuidade da aplicação do direito local desses povos, e eram muito flexíveis quanto à resolução de conflitos que surgiam envolvendo ambas as jurisdições.

Já na idade média ouve uma multiplicidade de manifestações normativas devido a enorme descentralização territorial que se deu com as invasões bárbaras. O conceito de direito na idade média é perfeitamente caracterizado conforme definição de Wolkmer:

Na idade média, a descentralização territorial e a multiplicidade de centros de poder configuram em cada espaço social um amplo espectro de manifestações normativas concorrentes, composto de costumes locais, foros municipais, estatutos das corporações de ofício, ditames reais, Direito Canônico e Direito Romano. Certamente foi com a decadência do Império Romano no Ocidente e com a fixação política dos povos nórdicos na Europa, que se solidificou a ideia de que a cada indivíduo seria aplicado o Direito de seu povo e de sua comunidade local ${ }^{11}$.

Via-se dessa forma uma completa descentralização dos costumes jurídicos, sendo estes peculiares a cada reino e a cada povo, com o intuito de obter maior eficácia. $\mathrm{O}$ fim da idade média foi marcado pelo início das formações nacionais absolutistas dos séculos XVII e XVIII, onde pouco a pouco as monarquias absolutistas estruturaram seu direito baseado no monismo centralizado.

O Estado que melhor exemplifica essa estrutura monista de direito foi o Estado francês pós-revolução francesa, integrando o direito francês sob uma legislação comum a todos os cidadãos. Segundo Boaventura de Sousa Santos:

No século XIX e primeiras décadas do nosso século, o problema do pluralismo jurídico teve amplo tratamento na filosofia e na teoria do direito. Foi sendo depois progressivamente suprimido pela ação de um conjunto de fatores em que se deve distinguir: as transformações na articulação dos modos de produção no interior das formações capitalistas centrais, de que resultou o domínio cada vez maior do modo de produção capitalista sobre o modo de produção pré-capitalista; a consolidação da dominação política do estado burguês nomeadamente através da politização progressiva da sociedade civil; o avanço concomitante das concepções jusfilosóficas positivistas ${ }^{12}$.

Este fenômeno é uma realidade social concreta, encontrada em diversos Estados, e

\footnotetext{
${ }^{11}$ WOLKMER, Antonio Carlos. Pluralismo Jurídico: fundamentos de uma nova cultura no direito. 3. ed. São Paulo: Alfa Omega, 2001, p. 184-185.

${ }^{12}$ SANTOS. Boaventura de Sousa. $O$ discurso e o poder. Ensaios sobre a sociologia retórica jurídica. Porto Alegre: SAFE, 1988, p.73.
} 
percebida especificamente em países marginalizados economicamente (como exemplo de Moçambique). Boaventura de Sousa Santos explicita que: “o pluralismo jurídico surge para preencher a lacuna promovida pela ausência do Estado em determinadas localidades"13.

A ideia de pluralismo jurídico é decorrente da existência de dois ou mais sistemas jurídicos, dotados de eficácia, concomitantemente em um mesmo ambiente espaço-temporal.

Em África primeiros estudos sobre a matéria reconheceram a presença de direito fora do Estado, onde era fácil identificar a presença de diferentes ordens jurídicas: de um lado, o direito europeu; do outro, os direitos costumeiros dos povos nativos.

A história de África, bem como o contexto em que foram elaboradas as primeiras etnografias, está fortemente presente na discussão contemporânea sobre a pluralidade jurídica deste continente. Já o pluralismo na América Latina só começou a ser pensado na sociedade contemporânea, surgindo como necessidade do direito resolver questões jurídicas no intuito principalmente de defender os direitos dos menos favorecidos, já que a realidade da América Latina, tal como em África, é marcada por grande desigualdade e pluralidade de etnias inferiorizadas socialmente.

Hoje, admite-se que a pluralidade jurídica existe virtualmente em todas as sociedades, mas reconhecem-se especificidades a vários níveis ${ }^{14}$.

Ora, com o advento do fenômeno globalização caracterizado por uma flexibilidade jurídica "procedente de negociações, de mesas redondas etc., constitui uma tentativa para encontrar uma nova forma de regulação social, outorgando ao Estado e ao direito um papel de guia (e não de direção) da sociedade", cujo caráter neofeudal de regulamentação social, enfatizado por Noël Roth, sinaliza a infinidade de foros de negociações descentralizados, em que é possível o reconhecimento de um pluralismo jurídico ${ }^{15}$.

Boaventura de Sousa Santos distingue o pluralismo jurídico em sentido amplo do pluralismo jurídico interno. O primeiro é o que acabou de ser mencionado. O segundo diz respeito ao pluralismo interno ao Estado e deriva da condição heterogénea do mesmo. O

\footnotetext{
${ }^{13}$ SANTOS. Boaventura de Sousa. O discurso e o poder. Ensaios sobre a sociologia retórica jurídica. Porto Alegre: SAFE, 1988, p. 75.

${ }^{14}$ GRIFFITHS, John. What is Legal Pluralism? Journal of Legal Pluralism and Unofficial Law, n. 24, 1986, p. $1-55$, passim.

${ }^{15}$ NOËL ROTH, André. O Direito em Crise: Fim do Estado Moderno? In: FARIA, José Eduardo (Org.). Direito e Globalização Econômica: Implicações e Perspectiva. São Paulo: Malheiros, p. 24-25.
} 
conceito de Estado heterogéneo "requer a coexistência de diferentes lógicas de regulação executadas por diferentes instituições do Estado com muito pouca comunicação entre si"16. A heterogeneidade do Estado deriva em grande medida da porosidade acima referida, que é tanto maior quanto mais intensa é a globalização.

Deste modo, pode-se dizer que o pluralismo jurídico questiona, portanto, os alicerces da teoria política e da jurisprudência liberais, principalmente no que diz respeito à congruência entre o território, o Estado e o direito, ou seja, a centralidade do direito elaborado pelo Estado e a exigência de exclusividade no ordenamento normativo da vida social ${ }^{17}$.

Assim, o Pluralismo Jurídico apresenta-se como o fenômeno que possibilita o surgimento de "direitos" extraestatais, ou seja, a possibilidade que existe do Estado não ser o único a emanar/deter normas. "Esse fenômeno reconhece como legítimas, as relações jurídicas criadas por grupos "marginais", no plano da luta social por direitos e pela democracia, como por exemplo, as lutas dos grupos pró-moradia, pró-cidadania" etc. ${ }^{18}$ Podese afirmar, por outro lado, que o pluralismo jurídico consiste em um conjunto de diferentes sistematizações, sob a forma plural, que coexistem em um mesmo espaço social e período histórico, nos quais se encontram presentes o direito estatal e também manifestações não oficiais de ordenação legal. Francis Snyder menciona que os sistemas plurais são parte do mesmo sistema, cada qual em um contexto particular, comumente interligados pelos mesmos microprocessos sociais ${ }^{19}$.

Portanto, o pluralismo jurídico se caracteriza por uma aparente "multiplicidade das fontes e das soluções de direito bem dentro de uma ordem jurídica, o que é descrito, em termos de sistemas, como sendo a presença de subsistemas no interior de um mesmo sistema jurídico." ${ }^{20}$ Depois desta breve resenha sobre o conceito e origem do pluralismo jurídico, passa-se agora analisar este fenômeno no contexto moçambicano.

\footnotetext{
${ }^{16}$ SANTOS, Boaventura de Sousa. O Estado heterogéneo e o pluralismo jurídico. In: SANTOS, Boaventura de Sousa; TRINDADE, João Carlos (Orgs.). Conflito e Transformação Social: Uma Paisagem das Justiças em Moçambique. v. I. Porto: Afrontamento, 2003, p. 63.

17 RANDEIRA. Shalino. Pluralismo Jurídico, soberania fraturada e direitos de cidadania diferenciados: instituições internacionais, movimentos sociais e Estado pós-colonial na Índia. Trad. de Ana Cláudia Jorge. In: SANTOS, Boaventura de Sousa (Org). Reconhecer para Libertar: os caminhos do cosmopolitismo multicultural. Rio de Janeiro: Civilização Brasileira, 2003, p. 467.

18 MEDRADO, Luiz Flávio Matos. Do monismo ao pluralismo jurídico. JurisWay. Disponível em: < http://www.jurisway.org.br/v2/dhall.asp?Id_dh=4280 >. Acesso em 05 de mar. de 2013.

${ }^{19}$ SNYDER, Francis apud MERRY, Sally Engle. Legal pluralism. Law \& Society Review, v. 22, n. 5, 1988, p. 873.

${ }^{20}$ ARNAUD, André-Jean Arnaud; FARINÃS DULCE, Maria José. Introdução à analise sociológica dos sistemas jurídicos. Rio de Janeiro: Renovar, 2000, p. 362.
} 


\section{PLURALISMO JURÍDICO EM MOÇAMBIQUE}

\subsection{O pluralismo jurídico moçambicano: o palimpsesto de políticas e culturas jurídicas}

Boaventura de Sousa Santos serve-se de uma metáfora para caracterizar a sociedade moçambicana: o palimpsesto de políticas e culturas jurídicas. Entre o período colonial e o presente, o Estado Moçambicano passou por uma série de modelos políticos, cujas rupturas não os apagaram de vez.

Desde 1975 até hoje, foram várias as transformações radicais, como o fim do modelo colonial; a construção do Estado socialista; e a criação de uma economia neoliberal capitalista e de uma democracia multipartidária. Três culturas político-jurídicas eurocêntricas (colonial, socialista/revolucionária, capitalista/democrática) cruzam-se entre si e com as tradicionais, mostrando que o binómio tradicional/moderno é muito mais complexo do que à primeira vista se poderia pensar.

\subsubsection{O Estado colonial}

No período de implantação colonial efetiva no território de Moçambique, cujo impulso histórico pode ser definido a partir da histórica Conferência de Berlim (que teve lugar entre os dias 19 de Novembro de 1884 e 26 de Fevereiro de 1885), em que uma das principais decisões assentou na premissa de "dominar e administrar os territórios efetivamente". ${ }^{21}$

A colonização em Moçambique inicialmente foi um processo que teve a suposta missão de expandir a então chamada civilização "superior" europeia para as populações colonizadas, consideradas primitivas, selvagens ou atrasadas, mas que encobria, de fato, objetivo associados à obtenção de matéria-prima e mão de obra escrava. Serra narra que:

a suposta missão civilizacional está patente, a título de exemplo, no artigo 2 do Ato
Colonial aprovado pelo Decreto-Lei n. ${ }^{\circ} 22465$, de 11 de Abril de 1933, segundo o
qual "É da essência orgânica da Nação Portuguesa desempenhar a função histórica
de possuir e colonizar domínios ultramarinos e de civilizar as populações indígenas

${ }^{21}$ MAR, Eli. J. E. Exploração Portuguesa em Moçambique 1500 - 1973. Esboço Histórico. v. I. Kastrup: African Studies, 1974, p. 62. Apud SERRA, Carlos Manuel. Estado, Pluralismo Jurídico e Estado, Pluralismo Jurídico $e$ Pluralismo Jurídico Recursos Naturais. Disponível em: <http://www.cfjj.org.mz/img/pdf/microsoft_word_-_trabalho_pluralismo_juridico_1_.pdf>. Acesso em 25 de fev. de 2013. 
que neles se compreendam, exercendo também a influência moral que lhe é adstrita pelo Padroado do Oriente ${ }^{22}$.

Este instrumento legal tinha por objetivo vincar a diferenciação do tratamento jurídico dos europeus e dos indígenas. Assim, por meio desse instrumento foi criada a Secretaria de Negócios Indígenas (SNE), "entidade à qual competia administrar a organização da justiça indígena, regulamentar os "deveres dos "régulos"23 e outras atividades gentílicas, providenciar a codificação dos usos e "costumes cafreais", determinar e fixar terrenos que deveriam ficar exclusivamente reservados para os indígenas, organizar o fornecimento de trabalhadores indígenas para os serviços públicos e particulares, entre outros". ${ }^{24}$

Assim, a política colonial em Moçambique apresentava seis principais características que diziam respeito à relação como era o modo de vida das populações locais - “(1) o pluralismo jurídico na era colonial; (2) a rede de lideranças locais; (3) o estatuto jurídico das populações locais; (4) o trabalho forçado; (5) a codificação dos direitos costumeiros; (6) e, por último, a terra e recursos naturais ao serviço dos interesses do Estado colonial." ${ }^{25}$

O pressuposto da dominação colonial Portuguesa em Moçambique estava assentada em bases raciais e as populações de origem africana eram até à fase última da colônia tratadas de forma pejorativa por "nativas" ou "indígenas", como que se pessoas de nível inferior se tratassem. O colonialismo assentou em um postulado rácico, "ainda que juridicamente não tenha ganhado contornos expressos como na vizinha África do Sul, na qual foi implantada uma política e legislação sobre a separação racial"26, o racismo era a principal característica. Daí que se pode afirmar que o pluralismo jurídico no período colonial constituiu "um projecto no qual o Estado colonial se assumiu como pólo ordenador da diversidade, com a correspondente 'missão' de fixar não apenas as regras reguladoras do funcionamento dos sistemas jurídicos plurais, como também os estatutos jurídicos das populações neles

\footnotetext{
${ }^{22}$ SERRA, Carlos Manuel. Estado, Pluralismo Jurídico e Estado, Pluralismo Jurídico e Pluralismo Jurídico Recursos Naturais. Disponível em: <http://www.cfjj.org.mz/img/pdf/microsoft_word__trabalho_pluralismo_juridico_1_.pdf $>$. Acesso em 25 de fev. de 2013.

${ }^{23}$ Essa expressão pretendeu originalmente diminuir a carga semântica da palavra "rei" quando aplicada a africanos, tendo designado detentores de posições políticas com estatutos tão díspares como os imperadores de Gaza (um império moçambicano que abrangia, no seu apogeu, toda a área costeira entre os rios Zambeze e Maputo e tinha a sua capital em Manjacaze, na atual província moçambicana de Gaza) e os chefes subalternos que administravam pequenas partes do território liderado pelos seus chefes de linhagem. No século XX, essa figura veio a ser integrada na estrutura administrativa colonial para efeitos de recolha de impostos, de controlo e de mobilização laboral de "indígenas".

${ }^{24}$ MAR, Eli. J. E. Exploração Portuguesa em Moçambique 1500 - 1973. Esboço Histórico. v. I. Kastrup: African Studies, 1974, p. 65 - 66.

${ }^{25}$ SERRA, Carlos Manuel. Op. cit., p. 7-8.

${ }^{26}$ Ibid., p. 8.
} 
envolvidas, face à ordem jurídica hegemónica"27.

O exemplo mais paradigmático foi a aprovação do Código Civil Português (Código de SEABRA), aprovado por Carta de Lei em 1 de Julho de 1887, que foi tornado extensivo ao espaço colonial, incluindo Moçambique, em 1869, por meio de Decreto de 18 de Novembro de 1869, ressalvando-se os usos e costumes das populações indígenas que não se opusessem à moral e à ordem pública. O preâmbulo do Decreto n. ${ }^{\circ} 12$ 533, de 27 de Novembro de 1926, que promulgou o Estatuto Político, Civil e Criminal dos Indígenas de Angola e Moçambique, disse o seguinte: "Não se atribuem aos indígenas, por falta de significado prático, os direitos relacionados com as nossas instituições constitucionais" ${ }^{28}$.

Foi nesse contexto que em 1914 é aprovado o primeiro código de indigenato, o Estatuto Político Civil e Criminal dos Indígenas das Colônias de Angola e Moçambique, por meio do Decreto n..$^{\circ} 12$ 533, de 23 de Outubro de 1926, e que, 3 anos mais tarde, deu origem a um novo Estatuto, aprovado por meio do Decreto n. ${ }^{\circ} 16$ 473, de 6 de Fevereiro de 1929, que mantiveram, quase na íntegra, os princípios e regas fundamentais da política colonial estatuídos na Lei n. ${ }^{\circ} 277$, de 15 de Agosto de $1914^{29}$.

Influenciado pelo modelo francês de colonização, a partir 1917, a Administração colonial portuguesa criou uma categoria nova - o assimilado, categoria social não sujeita ao trabalho forçado, com base no chamado modelo de assimilação, que caracterizou igualmente as relações entre a França e as suas colônias, em contraposição aos modelos da autonomia e da sujeição, que caracterizou, tendencialmente, as políticas coloniais do Reino Unido e do Reino dos Países Baixos, respectivamente ${ }^{30}$.

Eli Mar 2 citado por Serra, refere-se assim à instauração de um sistema baseado na agregação da população em três categorias ou castas distintas: os "assimilados", os “civilizados" e os "indígenas" 31.

\footnotetext{
${ }^{27}$ SILVA, Cristina Nogueira da. Codificação de Usos e Costumes na Doutrina Colonial. Quaderni Fiorentini per la Storia del Pensiero Giuridico Moderno, n. 33-34, t. II, 2004-2005, p. 901.

${ }^{28}$ SERRA, Carlos Manuel. Estado, Pluralismo Jurídico e Estado, Pluralismo Jurídico e Pluralismo Jurídico Recursos Naturais. Disponível em: <http://www.cfjj.org.mz/img/pdf/microsoft_word_trabalho_pluralismo_juridico_1_.pdf $>$. Acesso em 25 de fev. de 2013.

${ }^{29}$ CUNHA, J. M. da Silva, Questões Ultramarinas e Internacionais (Direito e Política), p. 16-18. Apud SERRA, Carlos Manuel. Estado, pluralismo jurídico e Estado, pluralismo jurídico e pluralismo jurídico e recursos naturais. Disponível em: http://www.cfjj.org.mz/IMG/pdf/Microsoft_Word__Trabalho_Pluralismo_Juridico_1_.pdf. Acessado em 25de fevereiro de 2013.p.16

${ }^{30}$ Loc. cit.

31 MAR, Eli. J. E. Exploração Portuguesa em Moçambique 1500 - 1973. Esboço Histórico. v. I. Kastrup:
} 
Outro instrumento que delineava o estatuto dos indígenas foi o Ato Colonial de 1933, aprovado pelo Decreto-lei n. ${ }^{\circ} 22$ 465, de 11 de Abril de 1933, que estabelecia no artigo 22 que “nas colônias atender-se-á ao estatuto de evolução dos povos nativos havendo estatutos especiais dos indígenas que estabeleçam para estes, sob influência do direito público e privado português, regimes de contemporização com os seus usos e costumes individuais, domésticos e sociais, que não sejam incompatíveis com a moral e com os ditames da humanidade". 32

Silva Cunha, ao analisar o quadro jurídico colonial saído da Constituição Portuguesa de 1933, justificou a opção por um estatuto jurídico especial para os indígenas da seguinte maneira:

os indígenas estão sujeitos a uma ordem jurídica especial porque o seu estado de civilização o impõe. É com fundamento em considerações tiradas da observação do estado pessoal de facto dos indígenas que se criam para eles estatutos especiais, em nome das necessidades práticas da política e administração colonial e com o objectivo de proteger as suas pessoas e bens, evitando que os não indígenas, valendo-se da superioridade de cultura e de prestígio que sempre cerca os pertencentes ao grupo colonizador, comeram contra eles abusos e espoliações. ${ }^{33}$

Em 1954 foi aprovado o Decreto-lei de 20 de Maio de 1954, e que era uma lei que visava a "assimilação" dos indígenas na cultura colonial (ocidental). Consequentemente, em 1961 por reformas introduzidas por Adriano Moreira quando foi Ministro do Ultramar, tendo presente a conjuntura internacional caracterizada pela emergência do movimento independentista ou de descolonização, bem como da emergência de nacionalismo no seio das colônias portuguesas, por meio do Decreto-Lei n. 43 893, de 6 de Setembro de 1961, procedeu à abolição do Estatuto do Indigenato.

African Studies, 1974, p. 135. Apud SERRA, Carlos Manuel. Estado, Pluralismo Jurídico e Estado, Pluralismo Jurídico e Pluralismo Jurídico Recursos Naturais. p. 17. Disponível em: <http://www.cfjj.org.mz/img/pdf/microsoft_word_-_trabalho_pluralismo_juridico_1_.pdf>. Acesso em 25 de fev. de 2013.

32 SERRA, Carlos Manuel. Estado, Pluralismo Jurídico e Estado, Pluralismo Jurídico e Pluralismo Jurídico Recursos Naturais, p. 17-18. Disponível em: <http://www.cfjj.org.mz/img/pdf/microsoft_word__trabalho_pluralismo_juridico_1_.pdf>. Acesso em 25 de fev. de 2013.

${ }_{33}$ CUNHA, J. M. da Silva, Questões Ultramarinas e Internacionais (Direito e Política), p. 214, citado por SERRA, Carlos Manuel. Estado, pluralismo jurídico e Estado, pluralismo jurídico e pluralismo jurídico e recursos naturais. Disponível em: http://www.cfjj.org.mz/IMG/pdf/Microsoft_Word__Trabalho_Pluralismo_Juridico_1_.pdf. Acessado em 25de fevereiro de 2013. p.17-18. 
2.1.2. Monismo estadualista no período pós Independência: Estado, o único criador do direito

Após a proclamação da República de Moçambique, no dia 25 de Junho de 1975, iniciou-se um período histórico de um autêntico Estadualismo jurídico, com contornos de positivismo, no sentido de que só se reconhecia ao Estado o papel de criador de direito, bem como apenas competia às instâncias formais representadas pelos tribunais populares e às novas estruturas político-administrativas criadas ao nível da base - os grupos dinamizadores, a função de resolução de litígios ${ }^{34}$.

Em 1975, o projeto socialista moçambicano, com alicerces no Marxismo, "passava pelo "escangalhamento" 35 de todos os vestígios coloniais e pela construção de uma nova sociedade ${ }^{36}$.

\begin{abstract}
No período que se seguiu à independência, houve um processo radical de «escangalhamento do aparelho do estado colonial, suas normas, sua filosofia». Tal processo que se desencadeou sob o signo de «combate ao burocratismo» redundou numa verdadeira «desracionalização» do Aparelho do Estado, cujos traços mais salientes foram: «a desnormatização, a ideologização, a desprofissionalização e a desrotinização». Verificou-se, portanto neste momento, a substituição das normas pelos princípio spolíticos, domínio da gestão dos recursos humanos na substituição de critérios meritocráticos por critérios substantivos. O modelo de organização e funcionamento do aparelho do estado com as características que atrás descrevemos revelou profundas fragilidades nos mecanismos operacionais ${ }^{37}$.
\end{abstract}

Com o escangalhamento do aparelho de Estado Colonial ${ }^{38}$, Moçambique foi conhecendo uma evolução jurídica em especial às normas judiciais, apesar da Constituição de 1975 tratar de forma bastante genérica a organização judiciária, consagrando as seguintes regras e princípios: reserva da função judicial para os tribunais; subordinação dos tribunais ao poder político, particularmente à Assembleia da República a quem prestavam contas; principio da legalidade; prevenção e educação no cumprimento da lei; independência dos juízes e obediência à lei no exercício das suas funções; organização hierárquica do Ministério Público e subordinação ao Procurador-Geral da República; e o princípio de que o Tribunal

\footnotetext{
${ }^{34}$ SERRA, Carlos Manuel. Estado, Pluralismo Jurídico e Estado, Pluralismo Jurídico e Pluralismo Jurídico Recursos Naturais, p. 31. Disponível em: <http://www.cfjj.org.mz/img/pdf/microsoft_word_trabalho_pluralismo_juridico_1_.pdf $>$. Acesso em 25 de fev. de 2013.

${ }_{35}$ A expressão usada pela Frente de libertação de Moçambique (FRELIMO) logo a pós conquistar a independência de Portugal em 1975 e significava a destruição do sistema de administração colonial vigente.

${ }^{36}$ ARAÚJO, Sara; JOSÉ, André. Pluralismo jurídico, legitimidade e acesso à justiça. Instâncias comunitárias de resolução de conflitos no Bairro de Inhagoia «B» - Maputo. Oficina do CES. n. 284. Coimbra: CES, 2007, p.7.

${ }^{37}$ POMBAL, António. O Poder executivo na experiência Moçambicana. In: Controle Social do Poder Político em Moçambique Divisão de Poderes. Nampula: Centro de Pesquisa Konrad Adenauer, 2003, p. 22.
} 
Supremo (que viria a ser constituído anos mais tarde) seria dotado da função de garantir a aplicação uniforme da lei nos tribunais.

A Resolução sobre Justiça do Comitê Central da FRELIMO ${ }^{39}$ (8 ${ }^{a}$ Sessão, 1976) definiu a prioridade política de destruir a estrutura judicial colonial, como um dos meios de combate ao "Estado colonial-capitalista". Assim, instituiu-se o princípio da participação popular na administração da justiça, intervindo nos tribunais juízes leigos (eleitos) ao lado dos juízes profissionais. Deste modo, “o novo sistema judiciário [devia] exprimir o poder da aliança operário-camponesa e refletir a ditadura da maioria explorada". Esta opção levou a que fossem afastadas da administração da justiça as entidades conotadas com o poder colonial, como é o caso das autoridades tradicionais.

Assim, o Decreto-Lei n. ${ }^{\circ}$ 4/75, de 16 de Agosto, proibiu o exercício da advocacia e das funções de consultoria jurídica, solicitadoria, procuradoria judicial ou extrajudicial, a título privado. Criou o Serviço Nacional de Consulta e Assistência Jurídica (SNCAJ), na dependência da Procuradoria-Geral da República, que devia cumprir aquelas funções. Este decreto nunca chegou a ser regulamentado e, por isso, o SNCAJ jamais entrou em funcionamento. Posteriormente, por meio da Lei n. ${ }^{o}$ 3/86, de 16 de Abril, foi criado, em sua substituição, o Instituto Nacional de Assistência Jurídica (INAJ), subordinado ao Ministério da Justiça, cujo Estatuto Orgânico foi previsto no Decreto n. ${ }^{\circ}$ 8/86, de 30 de Dezembro. Só os membros do INAJ poderiam praticar atos próprios da profissão, designadamente exercer o mandato judicial ou consulta jurídica.

No âmbito do INAJ estavam previstas três categorias de defensores, com diferentes competências: advogados, com licenciatura em direito; técnicos jurídicos, com bacharelato em direito ${ }^{40}$; assistentes jurídicos, habilitados com cursos de formação específica.

No entanto, a inscrição como advogado só podia ser efetuada pelos licenciados em direito depois de completarem o estágio com aproveitamento. Para a inscrição como técnico jurídico exigia-se o bacharelato em direito ou equivalente e igualmente um estágio. A inscrição como assistente jurídico era permitida àqueles que estivessem habilitados com cursos de formação jurídica reconhecidos por entidade competente.

Por outro lado, registrou-se a abrangência excessiva do âmbito de ação; indefinição do modelo de organização caráter centralista do Estado, verticalização de relacionamento entre

\footnotetext{
${ }^{38}$ Loc. cit.

${ }^{39}$ Partido que dirigiu a luta armada de libertação nacional de Moçambique e que governa o país até a data.

${ }^{40}$ Entende-se por bacharéis em direitos, estudantes de direito que não tenham terminado o curso de direito mas que tenho feito no mínimo o terceiro ano do curso.
} 
os órgãos de administração, propagação territorial, operação setorial, reprodução dos órgãos centrais e abrangência absorvente no âmbito da economia. O Estado procurou pôr fim à justiça dualista e às autoridades tradicionais, vistas como aliadas do poder colonial, e criar um sistema de justiça que se pretendia indígena, mas não tribal. Assim, em 1978, foi aprovada a Lei Orgânica dos Tribunais Populares, que previa a criação de tribunais populares em diferentes escalões territoriais, onde juízes profissionais trabalhavam ao lado de juízes eleitos pela população.

Na década de 1980, ocorreu o fracasso econômico do projeto socialista. Em 1984, o governo moçambicano aderiu às Instituições de Breton Woods (IBWs), nomeadamente ao Banco Mundial e ao Fundo Monetário Internacional. Mais tarde, em 1990, foi aprovado um novo texto constitucional instituindo o multipartidarismo.

A Constituição da República de Moçambique de 1990, nesse "contexto de construção de uma democracia liberal, consagrou os princípios da separação de poderes, da independência, da imparcialidade, da irresponsabilidade e da legalidade, lançando bases para a produção de alterações substanciais na organização judiciária. Assim, a Lei dos Tribunais Populares foi substituída pela Lei Orgânica dos Tribunais Judiciais de $1992^{״ 41}$ e no mesmo ano foram criados os tribunais comunitários que funcionavam com juízes eleitos pela comunidade e a desempenhar o papel que cabia aos tribunais populares de localidade e de bairro ${ }^{42}$. No entanto, não chegaram a ser regulamentados.

Os tribunais comunitários são classificados por Boaventura de Sousa Santos como o híbrido jurídico por excelência, por se encontrarem num limbo institucional, na medida em que são reconhecidos por lei, mas estão fora do sistema judicial e não estão, até hoje, regulamentados ${ }^{43}$. As profissões jurídicas foram liberalizadas por força da Constituição de 1990, deixando de ser proibido o exercício privado da advocacia. Assim, em 1994 foram publicados dois diplomas que regulam os serviços jurídicos e o sistema de assistência judiciária: a Lei n. ${ }^{\circ}$ 7/94, de 14 de Setembro, que cria a Ordem dos Advogados de Moçambique (OAM) e aprova o respectivo Estatuto Orgânico, consagrando a advocacia como

\footnotetext{
${ }^{41}$ ARAÚJO, Sara. O Estado moçambicano e as justiças comunitárias: Uma história dinâmica de imposições e respostas locais diferenciadas. 7. ${ }^{\circ}$ Congresso Ibérico de Estudos Africanos, 2010. Disponível em: < http://www.ces.uc.pt/myces/UserFiles/encontros/1097_CIEA7_29_ARA\%DAJO_O\%20Estado\%20mo\%E7ambi cano\%20e\%20as\%20justi\%E7as\%20comunit\%E1rias.pdf >. Acesso em 05 de mar. de 2013, p. 7.

${ }^{42}$ TRINDADE, João Carlos. Rupturas e continuidades nos processos políticos e jurídicos In: SANTOS, Boaventura de Sousa; TRINDADE, João Carlos (Orgs.). Conflito e Transformação Social: Uma Paisagem das Justiças em Moçambique. v. I. Porto: Afrontamento, 2003, p. 97-128.

${ }^{43}$ SANTOS, Boaventura de Sousa. O Estado heterogéneo e o pluralismo jurídico. In: SANTOS, Boaventura de Sousa; TRINDADE, João Carlos (Orgs.). Conflito e Transformação Social: Uma Paisagem das Justiças em Moçambique. v. I. Porto: Afrontamento, 2003, pp. 47-128.
} 
um dos três pilares da administração da justiça; e a Lei n. ${ }^{\circ}$ 6/94, de 13 de Setembro, que cria o Instituto de Patrocínio e Assistência Jurídica (IPAJ), como corolário do princípio constitucional do livre acesso dos cidadãos aos tribunais, do direito de defesa e do direito de assistência e patrocínio judiciário.

O ponto seguinte apresenta algumas considerações sobre a "constitucionalização" do pluralismo jurídico em Moçambique.

\subsection{Tratamento constitucional do pluralismo jurídico em Moçambique}

A revisão constitucional de 2004 veio consagrar diversas alterações no ordenamento jurídico-constitucional, com as quais a Lei de Bases da Organização Judiciária, que agora se propõe, deve conformar-se. Para além do reconhecimento, já referido, do pluralismo jurídico (artigo $4^{\circ}$ ), a Constituição enfatiza, no seu artigo $11^{\circ}$, alínea g), "a promoção de uma sociedade de pluralismo, tolerância e cultura de paz", e proclama, no artigo $118^{\circ}$, que "o Estado reconhece e valoriza a autoridade tradicional legitimada pelas populações e segundo o direito consuetudinário" (n. ${ }^{\circ}$ 1) e "define o relacionamento da autoridade tradicional com as demais instituições e enquadra a sua participação na vida econômica, social e cultural do país, nos termos da lei" (n. $\left.{ }^{\circ} 2\right)$. Consequentemente, a atividade destas autoridades na resolução de litígios não deve ser proibida, antes pelo contrário, deve ser encorajada, sempre que for consentida pelas partes e as suas decisões não violarem os princípios e as normas constitucionais.

Ora, antes de aprofundarmos o tratamento constitucional do pluralismo em Moçambique, necessário se torna discorrer a respeito do ensinamento de Canotilho, que com a complexidade e heterogeneidade do ordenamento jurídico atual, a necessidade atual do jurista constitucional deve ser a de elaborar novos modelos normativos. Pois, para delinear o quadro moral e racional de sua Constituição, um Estado precisa considerar o pluralismo jurídico, interno e transnacional, na medida em que normas constitucionais atualmente têm por fontes não apenas o estrito positivismo kelseniano, mas incorporam referências da própria realidade à qual elas se destinam. Portanto, o sistema jurídico não se compõe mais apenas de normas puras, devendo incorporar os valores presentes no contexto ao seu redor, que também o integra. Dessa simbiose deriva sua capacidade de autorregenerar-se à medida que a evolução histórico-social se impõe ao direito.

Se considerarmos a norma fundamental como um elemento unificador da realidade, 
devemos estar abertos às suas transformações, de modo a incluir em seu bojo os novos direitos considerados legítimos pela sociedade, aos quais também se estende a proteção legal em um Estado Democrático de Direito.

Podemos arriscar dizer que foi também com esse espírito que o legislador constituinte moçambicano consagrou no artigo $4^{\circ}$ da Constituição da República de Moçambique de 2004 o pluralismo jurídico, reconhecendo "a existência dos vários sistemas normativos e de resolução de conflitos que coexistem na sociedade moçambicana, na medida em que não contrariam os valores e princípios fundamentais da constituição”.

Ora, o legislador constituinte Moçambicano ao referir que só serão reconhecidos sistemas normativos de resolução de conflito que não contrariem os valores e princípios fundamentais, procurou assegurar um pluralismo equilibrado e limitado pela ordem jurídica formal e, ao mesmo tempo, permitiu a existência de um pluralismo compreensivo referente aos elementos autorreguladores da sociedade, com finalidade de assegurar que os diversos sistemas de resolução não positivados que coexistem na sociedade moçambicana tivessem a proteção constitucional. $\mathrm{Na}$ verdade o legislador constituinte apenas reconheceu constitucionalmente prática que já era habitual na sociedade moçambicana.

Esse reconhecimento por parte do legislador constituinte moçambicano corresponde a uma necessidade social inelutável "conforme com o princípio da adequação, o qual constitui um corolário da finalidade precípua a que se dirigem as regras jurídicas". Na medida em que estas visam disciplinar a vida em sociedade segundo certa ordem de valores, importa que estejam em conformidade com o sentimento de justiça dos seus destinatários, sob pena de serem rejeitadas pelo corpo social que visam conformar o que, em última análise, conduz (como tantas vezes ocorre) à sua ineficácia.

Por outro lado, a Constituição da República de Moçambique, para além de consagrar que os preceitos constitucionais relativos aos direitos fundamentais são interpretados e integrados de harmonia com a Declaração Universal dos Direitos do Homem e a Carta Africana dos Direitos Humanos e dos Povos (art. 43..$^{\circ}$ ), também constitucionaliza o direito de ação popular $\left(\operatorname{art} .81^{\circ}\right.$ ), bem como reconhece o papel que as organizações sociais, como formas de associação com afinidades e interesses próprios, desempenham na promoção da democracia e na participação dos cidadãos na vida pública.

Assim, a Constituição reconhece que as organizações sociais contribuem para a 
realização dos direitos e liberdades dos cidadãos, bem como para a elevação da consciência individual e coletiva no cumprimento dos deveres cívicos (art. $78 .^{\circ}$ ), pelo que se torna imperativo que estas organizações possam atuar na promoção e defesa dos direitos dos cidadãos e designadamente tenham um papel ativo no novo sistema de acesso à justiça e ao direito, ao nível da informação, da consulta e do patrocínio jurídico. A Constituição reconhece, ainda, como já é consensual nas sociedades contemporâneas, que os tribunais judiciais há muito deixaram de ter o monopólio da administração da justiça, prevendo, expressamente, a possibilidade de serem criados mais tribunais comunitários.

Entretanto, é importante observar a advertência de Boaventura de Sousa Santos, segundo a qual o pluralismo pode induzir em erro. Apresenta uma conotação normativa, designa algo de bom, porque pluralista. Neste sentido, prefere a expressão "pluralidade de ordens jurídicas"44. O legislador constituinte moçambicano resguardou-se desse perigo ao referir que normativos e de resolução de conflitos que coexistem na sociedade moçambicana, só serão relevantes na medida em que não contrariem os valores e princípios fundamentais da constituição.

Ademais, o legislador constituinte moçambicano, ao instituir constitucionalmente o pluralismo jurídico, reconhece que "o Estado não detém o monopólio de produção de normas, de maneira que o direito não se resume ao direito Estatal, mas envolve também um direito vivo que surge no seio da própria sociedade, apresentando, às vezes, maior legitimidade do que os atos normativos emanados das instituições públicas"45.

$\mathrm{Na}$ verdade, fora do Estado há Direito Positivo dotado, portanto, de garantia jurídica e não apenas de garantias extrajurídicas, havendo equivalência entre o Direito Positivo estatal e o não estatal.

Portanto, a pluralidade de formas e de sistemas de resolução de conflitos existentes no Estado moçambicano aliados às normas positivas do Estado soberano, impuseram à Constituição o paradoxo da tolerância.

O pluralismo jurídico também encontra amparo constitucional em vários países do

\footnotetext{
${ }^{44}$ SANTOS, Boaventura de Sousa. O Estado heterogéneo e o pluralismo jurídico. In: SANTOS, Boaventura de Sousa; TRINDADE, João Carlos (Orgs.). Conflito e Transformação Social: Uma Paisagem das Justiças em Moçambique. v. I. Porto: Afrontamento, 2003, p. 52-53.

${ }^{45}$ CARVALHO, Lucas Borges de. Caminhos (e descaminhos) do pluralismo jurídico no Brasil. In: WOLKMER, Antonio Carlos; VERNAS NETO, Francisco Q.; LIXA, Ivone M. (Orgs.). Pluralismo jurídico: os novos caminhos da contemporaneidade. São Paulo: Saraiva, 2010, p. 14.
} 
mundo dos quais podemos citar: a Constituição em vigor na República da África do Sul reconhece a instituição, o estatuto e o papel da autoridade tradicional, exercidos de acordo com o direito costumeiro e desde que não a contrariem (art. 211, n. ${ }^{\circ} 1$ ). Os tribunais devem fazer uso do direito costumeiro, nos casos em que este for aplicável, desde que não violem a Constituição ou a legislação ordinária (art. 211, n. ${ }^{\circ}$ 3).

Em 2003 foi aprovada a Traditional Leadership and Governance Framework Bill, que regula o direito costumeiro (de acordo com o estabelecido no art. 211, n. ${ }^{\circ} 3$ da Constituição), lei esta que prevê o funcionamento das autoridades tradicionais como instituições locais, à disposição das comunidades. No seguimento desta decisão têm vindo a ser criadas houses of traditional leaders e foi instituído o Conselho das Autoridades Tradicionais (nos termos do Council of Traditional Leaders Bill de 1996 e da Council of Traditional Leaders Act de 1997), de modo a garantir o funcionamento do sistema de direito costumeiro, conforme consagrado na actual Constituição (art. 212, n. ${ }^{\text {o }} 2$ alíneas a) e b)).

O projeto da nova Constituição do Quénia, que se encontra em debate, reconhece o conjunto das civilizações, das pessoas e comunidades baseadas nos valores e princípios constitucionais não escritos, nas tradições, nas lutas do presente e nas aspirações futuras.

Estabelece, ainda, a proteção dos valores culturais e o reconhecimento da cultura como a base do orgulho nacional e da identidade. O funcionamento dos órgãos do Estado deve pautar-se, assim, pelos princípios da promoção do multiculturalismo, cooperação, compreensão, tolerância e respeito pelos diferentes costumes, tradições, crenças, línguas, práticas religiosas, sabedorias e filosofias que afirmem o desenvolvimento e respeito pela preservação da dignidade e do bem-estar do povo.

No Uganda, o Governo defende que os Local Council Courts (LCC) assumam um papel muito importante na administração da justiça. Estes LCC (que não estavam dependentes do sistema judiciário formal) foram criados a partir dos Resistance Committee Courts, tendo sido implantados em regiões onde a justiça formal não estava presente ${ }^{46}$. Os LCC conhecem de delitos de pequena gravidade (de foro cível e criminal), privilegiando na sua atuação a reconciliação, a compensação e o perdão.

Hoje, estes tribunais encontram-se incorporados na base do sistema judiciário, sendo

${ }^{46}$ UGANDA. Ministry of Local Government of the Republic of Uganda (2003). Local Councils Administration of Justice. Guides for Local Council Courts. Disponível em: <http://www.molg.go.ug/docs/Local 
possível recorrer da sua decisão para um tribunal judicial (magistrate’s court). Os Ministérios da Administração Local e da Justiça supervisionam conjuntamente a actuação dos LCC, pois estes, para além das questões jurídicas, intervêm também na administração local.

No entanto, pode ler-se num relatório do Ministério da Administração Local que aqueles tribunais enfrentam um conjunto de dificuldades e de obstáculos que precisam de ser resolvidos, como, por exemplo:

os LCC têm, geralmente, um fraco conhecimento do direito formal vigente; os membros do tribunal não têm acesso a materiais de referência essenciais; com frequência, não conhecem os direitos das crianças; as decisões do LCC são muitas vezes enviesadas em desfavor das mulheres; a documentação sobre os procedimentos do tribunal é escassa (afectando, nomeadamente, a questão dos recursos); os LCC estão ainda a lidar com casos que ultrapassam os limites da sua jurisdição, como por exemplo, violações ${ }^{47}$.

Na Namíbia, os tribunais comunitários resultam de uma reformulação dos antigos tribunais tradicionais. De acordo com a Community Courts Act (Lei n. ${ }^{\circ}$ 10, de 2003), as autoridades tradicionais podem requerer ao Ministro responsável pela área da justiça a criação de tribunais comunitários. A jurisdição dos tribunais comunitários circunscreve-se à área territorial de cada "comunidade tradicional". Não constituem uma jurisdição obrigatória, dependendo a sua intervenção do acordo das partes. Têm competência para decidir sobre todas as questões relacionadas com pedidos de compensação e de restituição de bens, desde que tutelada pelo direito costumeiro. Das decisões dos tribunais comunitários pode haver recurso para a estrutura formal dos tribunais, concretamente para os Magistrate's Courts, desde que o recorrente tenha esgotado todas as possibilidades de recurso existentes na estrutura do tribunal comunitário. Para a decisão do recurso o juiz presidente do Magistrate's Court pode nomear dois assessores, que conheçam o direito e as normas aplicadas e o funcionamento dos tribunais comunitários.

Em Cabo Verde encontramos outros exemplos de convivência entre os tribunais judiciais e as instâncias comunitárias de resolução de conflitos, aqueles não detendo o monopólio da resolução dos litígios. Realça-se a existência de estruturas "tradicionais" (Regedores ou Cabos-chefe) no período colonial e, após a independência, a implantação dos “tribunais de zona”, constituídos por juízes leigos. É reconhecido que os tribunais de zona,

CourtsGuide.pdf>. Acesso em 20 nov. 2013.

${ }^{47}$ UGANDA. Ministry of Local Government of the Republic of Uganda (2003). Local Councils Administration of Justice. Guides for Local Council Courts. Disponível em: <http://www.molg.go.ug/docs/Local CourtsGuide.pdf>. Acesso em 20 nov. 2013. 
enquanto forma de participação popular na administração da justiça, foram extremamente importantes para "aproximar mais a justiça das populações".

Jorge Fonseca é da opinião que se devem criar, a título experimental, em comarcas de maior movimento processual, tribunais de pequenas causas cíveis. $\mathrm{O}$ funcionamento destes tribunais seria marcado por princípios de simplicidade de procedimentos, informalidade, oralidade e procura de uma justa composição dos litígios por acordo das partes. Teriam competência para apreciar e decidir causas de valor não excedente aos da alçada dos tribunais de 1. ${ }^{\text {a }}$ instância, com incidência, entre outras a definir por lei, em ações destinadas a efetivar o cumprimento de obrigações que tenham por objeto prestações pecuniárias, ações relativas ao descumprimento contratual, ao arrendamento urbano, à administração e uso da propriedade, da superfície, do usufruto e de uso, de habitação, ações possessórias, de usucapião e acessão, de indemnização por prática de certos crimes de pequena gravidade, designadamente contra a propriedade e a honra, desde que não tenha havido participação criminal ou tenha havido desistência. Funcionariam com juízes licenciados ou bacharéis em direito ou togados ou com juízes leigos de idoneidade comprovada ${ }^{48}$.

As decisões não dependeriam de critérios de estrita legalidade, podendo os juízes decidir segundo a equidade, desde que obtido o acordo das partes ${ }^{49}$.

A Constituição da Colômbia consagra que "as Autoridades dos povos indígenas podem exercer funções jurisdicionais dentro do seu âmbito territorial, e em conformidade com as suas próprias normas e procedimentos, sempre que não sejam contrários à Constituição e às leis da República. A lei estabelecerá as formas de coordenação desta jurisdição especial com o sistema jurídico nacional" (art. 246).

Assim, no seguimento da Constituição de 1991, a Lei n. ${ }^{\circ}$ 270, de 1996, Estatutaria de la Administración de Justicia, incorpora os juízes de paz e a jurisdição das comunidades indígenas na estrutura geral da Administração da Justiça, como parte da organização judiciária.

Também em Portugal, o artigo 202, n.o 4, da Constituição da República Portuguesa, determina que a "lei poderá institucionalizar instrumentos e formas de composição não jurisdicional de conflitos", sendo de salientar a criação, nos últimos anos, das Comissões de

${ }^{48}$ FONSECA, Jorge Carlos de Almeida (Coord.). Estudo sobre o estado da Justiça em Cabo Verde. Praia: Gabinete do Ministro da Justiça, Governo de Cabo Verde, 2002. 
Protecção de Crianças e Jovens, dos Centros de arbitragem institucional (por exemplo, centros de arbitragem de conflitos de consumo, de conflitos desportivos etc.) e dos Julgados de Paz.

Portanto, como se viu, o reconhecimento constitucional de instrumentos e formas de composição não judicial de conflitos não é caso isolado de Moçambique.

O ponto seguinte apresenta alguns dos resultados de um estudo de caso realizado por Sara Araújo no bairro Jorge Dimitrov e procura exemplificar uma das configurações dos vários sistemas normativos de resolução de conflitos que coexistem na sociedade moçambicana.

\subsection{Estudo de caso. Justiças cruzadas no bairro Jorge Dimitrov}

Para melhor elucidarmos os motivos pelos quais Boaventura de Sousa Santos apelidou o pluralismo jurídico em Moçambique de palimpsesto político e jurídico, torna-se imperioso citar como um dos vários exemplos o Estudo de Araújo ${ }^{50}$ sobre justiças cruzadas num dos bairros da capital Moçambicana - Maputo - Jorge Dimitrov. ${ }^{51}$ Assim, segundo o referido estudo, atualmente não existe no bairro Jorge Dimitrov um tribunal comunitário em funcionamento. Entretanto, nos anos 1980 foi criado um tribunal popular de base que, segundo a lei, deveria ter sido transformado em tribunal comunitário e permanecer em funcionamento nos dias de hoje. Diga-se, no entanto, que este tribunal deixou de funcionar, e a desempenhar as suas funções encontra-se um gabinete de atendimento da organização Mulher Lei e Desenvolvimento (MULEIDE), que funciona na sede do Grupo Dinamizador ${ }^{52} .53$

\footnotetext{
${ }^{49}$ Loc. cit.

${ }^{50}$ Sara Araújo, Licenciada em sociologia pela Universidade de Coimbra e doutoranda do Programa Direito, Justiça e Cidadania no Século XXI da mesma universidade. Investigadora do Centro de Estudos Sociais da Universidade de Coimbra. Foi membro da equipa de investigação binacional para a reforma da organização judiciária moçambicana, uma parceria entre o Centro de Estudos Sociais e o Centro de Formação Jurídica e Judiciária moçambicano.

${ }^{51}$ Jorge Dimitrov é um dos 12 bairros que constituem o distrito municipal n. ${ }^{\circ} 5$ da cidade de Maputo.

52 Em Moçambique, chamaram-se Grupos Dinamizadores às organizações de base da sociedade, a seguir à Independência Nacional, em 25 de Junho de 1975. Os Grupos Dinamizadores de Local de Trabalho foram formados em todas as empresas, comerciais, industriais ou de serviços e nas repartições públicas, com o objetivo de estimular aumento de produtividade criticar os trabalhadores faltosos, assistir a direção principalmente nas suas relações com os restantes trabalhadores, evitar os roubos - e, mais importante, orientar Sessões de Esclarecimento semanais (aos sábados). Nestas sessões eram analisados os problemas do local de trabalho e discutidas as novas leis e orientações que iam surgindo. A partir de 1978, esses Grupos Dinamizadores foram substituídos por verdadeiras células da Frelimo - nesse momento já transformado em Parido Político, de ideologia marxista- leninista. Mais ou menos pela mesma altura, foram igualmente criados os Grupos de Vigilância, que tinham a função de detectar e denunciar - ou tentar eliminar - tentativas de sabotagem
} 
Estabelecida em Moçambique desde 1991, a MULEIDE é uma ONG centrada na defesa dos direitos das mulheres e da igualdade de oportunidades, cuja atuação se estende a diferentes áreas, entre as quais a de apoio na resolução de conflitos, assistência jurídica e patrocínio judiciário. ${ }^{54}$

As sessões de resolução de conflitos são conduzidas no bairro de Jorge Dimitrov pelo chamado "Grupo da Educação Legal da MULEIDE”, que é composto exclusivamente por membros da comunidade, entre estes encontram-se um Secretário de Bairro Adjunto do Grupo Dinamizador (SBA) e duas ex-juízas do tribunal comunitário que encerrou. Todos/as se intitulam "conselheiros/as", procurando distanciar-se do formalismo associado aos juízes. Tal como é frequente acontecer nos tribunais comunitários, o tipo de casos processados depende, em grande medida, da procura. ${ }^{55}$

O volume da procura é baixo. Durante os quinze dias úteis de observação de Sara Araújo, passaram por esta instância 16 casos. Assim, 37,5\% dos casos foram conflitos no seio do casal (expulsão da mulher de casa, divisão de bens em casos de divórcio, entre outros); $12,5 \%$ dos casos foram de reconhecimento de paternidade; $18,8 \%$ dos casos foram conflitos entre vizinhos (não devolução de bens, acusação de namorar o marido da vizinha, acusação de arrancar plantas); $18,8 \%$ foram conflitos relacionados com a posse de terrenos; houve um caso de uma mulher viúva, a quem a ex-mulher do marido falecido queria confiscar os bens; um caso em que uma mulher se queixa que o pai da filha deixou de apoiá-la financeiramente etc. Enfim, segundo este estudo, foram vários casos apresentados que careceram de formas de resolução de conflitos distintos do formal. ${ }^{56}$

\section{PURALISMO JURÍDICO NO BRASIL}

econômica. Já nos anos 80, surgiram os Comités Sindicais, que continuam até hoje, enquanto que as restantes estruturas praticamente deixaram de existir. Eram comitês compostos por oito a doze pessoas, liderados por um secretário, que passaram a desempenhar um conjunto de tarefas. Para além de funções como a mobilização das populações para a participação político-partidária, a segurança nacional, a organização de processos de produção coletiva e a execução de programas de educação, foram-lhes atribuídas inicialmente funções na área da justiça.

${ }^{53}$ ARAÚJO, Sara. Acesso à justiça e pluralismo jurídico em Moçambique. Resolução de litígios no bairro «Jorge Dimitrov». VI Congresso de Português de Sociologia. Mundos Sociais: Saberes e Práticas. 2008. Disponível na Internet: < http://www.aps.pt/vicongresso/pdfs/62.pdf >. Acesso em 05 de Março de 2013, p. 8.

${ }^{54}$ Loc. cit.

55 Loc. cit.

${ }^{56}$ ARAÚJO, Sara. Acesso à justiça e pluralismo jurídico em Moçambique. Resolução de litígios no bairro «Jorge Dimitrov». VI Congresso de Português de Sociologia. Mundos Sociais: Saberes e Práticas. 2008. Disponível na 


\subsection{Pluralismo jurídico e direito alternativo no Brasil}

O Direito Alternativo, como teoria, chegou ao Brasil na década de 1980, sendo marcado como um movimento de juízes, tendo tido grande repercussão, sobretudo nos estados do Sul do país (notadamente no Rio Grande do Sul). Este movimento foi inspirado nos modelos europeus, que o antecederam, de modo particular o modelo italiano iniciado na década de 1970. Consistia, inicialmente, em um grupo de magistrados que se reuniam na forma de um grupo de estudos na ânsia de democratizar o direito, abandonando uma visão dogmatizada que se tinha do mesmo ${ }^{57}$.

Este movimento, a partir daí, cresceu e se manifesta por todo o país, com decisões que fogem ao comum do direito e vão além da aplicação seca nos moldes de um positivismo radical. Ainda que a princípio estas não estejam vinculadas diretamente ao movimento do Direito Alternativo, pode-se afirmar que são expressões de um olhar alternativo para o direito $^{58}$.

A corrente do pluralismo jurídico no Brasil caracteriza-se por uma busca das fontes do direito não apenas nos meios convencionais aos quais a cultura jurídica estava acostumada. Trata-se uma visão dos atores sociais como também possíveis produtores de fenômenos jurídicos. Nesse sentido, Wolkmer aduz que:

\footnotetext{
Trata-se de extrair a constituição da normatividade não apenas mais e apenas das fontes ou canais habituais clássicos representados pelo processo legislativo e jurisdicional do Estado, mas captar o conteúdo e a forma do fenômeno jurídico mediante a informalidade de ações concretas de atores coletivos, consensualizados pela identidade e autonomia dos interesses do todo comunitário, num locus [grifo do autor] político, independente dos rituais formais de institucionalização ${ }^{59}$.
}

Para Wolkmer, o envolvimento e a participação dos grupos sociais se dão principalmente nos "novos movimentos sociais", que adotariam a forma de atores sociais,

\footnotetext{
Internet: < http://www.aps.pt/vicongresso/pdfs/62.pdf > . Acesso em 05 de Março de 2013, p. 8-9.

${ }^{57}$ PIRES, Caio José Leitão; GOMES, Raíza Feitosa. O pluralismo jurídico e a real participação da sociedade nas questões jurídicas - uma análise de caso. Âmbito Jurídico. Rio Grande, XIV, n. 91, ago. 2011. Disponível em: <http://www.ambitojuridico.com.br/site/index.php?n_link=revista_artigos_leitura\&artigo_id=9998>. Acesso em mar. 2013.

${ }^{58}$ Loc. cit.

${ }^{59}$ WOLKMER, Antonio Carlos. Pluralismo Jurídico: fundamentos de uma nova cultura no direito. 3. ed. São Paulo: Alfa Omega, 2001, p. 129.
} 
sendo protagonistas nas formas de criação da sociedade, inclusive do direito. ${ }^{60}$

Deve ser ressaltado que ao buscar essa proximidade social, o direito encontra grande complexidade, já que os conflitos e divergências estão postos na sociedade mesmo em grupos que são enxergados superficialmente como homogêneos. Assim é o caso ao qual está ligada a decisão do referido juiz, a prostituição, que tem sido vista de divergentes formas pelos movimentos sociais e em estudos feministas. O feminismo radical defende a visão das prostitutas como vítimas da opressão masculina, sendo tal atividade a expressão máxima da submissão feminina e, assim, agravante das desigualdades já existentes entre homens e mulheres, devendo ser extirpada ${ }^{61}$.

De outra perspectiva, o chamado feminismo liberal, que foi influenciado pela atuação de movimentos organizados de prostitutas, alega que a prostituição é um ato de autodeterminação sexual, e, portanto, um trabalho como outro qualquer, devendo ser, então, regulamentado. Nesse sentido, o presente trabalho também pretende analisar de que forma essas divergências são contempladas (ou não) pelas visões críticas do dogmatismo jurídico aqui já apresentadas ${ }^{62}$.

\subsection{Direito de Pasárgada}

No livro O Discurso e o Poder, resultado de estudos empíricos, realizados durante os anos 1970, numa comunidade do Rio de Janeiro, Boaventura de Sousa Santos afirma e analisa a existência de um direito, diferente do estatal, que vigora naquela comunidade, fruto da organização social entre os moradores ${ }^{63}$.

Segundo Souza Santos, o surgimento de Pasárgada na cidade do Rio de Janeiro se dá na década de 1930, quando seus primeiros habitantes instalaram-se em propriedades alheias e do governo. Existia, àquela época, abundante terra disponível, não havendo, portanto, muitos

\footnotetext{
60 WOLKMER, Antonio Carlos. Pluralismo Jurídico: fundamentos de uma nova cultura no direito. 3. ed. São Paulo: Alfa Omega, 2001, p. 129.

${ }^{61}$ PIRES, Caio José Leitão; GOMES, Raíza Feitosa. O pluralismo jurídico e a real participação da sociedade nas questões jurídicas - uma análise de caso. Âmbito Jurídico. Rio Grande, XIV, n. 91, ago. 2011. Disponível em: <http://www.ambitojuridico.com.br/site/index.php?n_link=revista_artigos_leitura\&artigo_id=9998>. Acesso em mar. 2013.

${ }^{62}$ Loc. cit.

63 FELISMINO, Lia Cordeiro. Pluralismo jurídico: um diálogo entre os pensamentos emancipatórios de Boaventura de Sousa Santos e Antônio Carlos Wolkmer. Anais do XIX Encontro Nacional do CONPEDI. Tema: Direitos Fundamentais e Transdisciplinaridade. Fortaleza, 9, 10, 11 e 12 de junho de 2010, p. 8486.
} 
conflitos a ela relacionados ${ }^{64}$.

As lides relacionadas à posse e propriedade das terras em Pasárgada foram aumentando com o passar dos anos e o crescimento populacional da favela. Uma vez que suas "propriedades" eram tidas como ilegais, a população não poderia recorrer à Justiça oficial, fazendo surgir, na comunidade, a associação de moradores, que passa a solucionar os conflitos locais $^{65}$.

Pasárgada originou-se a partir de ocupações em terrenos particulares, razão pela qual é tida, pelo direito oficial estatal, como ilegal, daí, o resultado de ser, praticamente, desconsiderado pelo Estado, conforme se constata da ausência de políticas públicas e da prestação de serviços públicos, entre eles, os mais básicos de infraestrutura, tais como o fornecimento de água e esgoto ${ }^{66}$.

Seus moradores, diante disso, geralmente não eram reconhecidos pelo Estado enquanto sujeito de direitos, mas tão somente como objetos de repressão criminal. Assim, diante da ausência do Estado (e aqui destaca-se, em especial, do direito estatal), os moradores de Pasárgada acabam por se organizar, de forma a melhorar o desenvolvimento da comunidade e garantir a segurança e a ordem nas relações sociais. ${ }^{67}$ Boaventura de Sousa Santos ensina que:

\begin{abstract}
Pasárgada é uma comunidade densamente povoada, no seio da qual se estabeleceu uma teia muito complexa de relações sociais entre os habitantes e entre estes, individualmente, e a comunidade no seu todo, algumas das quais têm origem em contratos (compra e venda, arrendamento, etc.) e outros negócios jurídicos que envolvem a propriedade, a posse e direitos reais vários sobre a terra e as habitações (ou parte delas) individualmente apropriadas. Tais relações têm uma estrutura homológica das relações jurídicas. No entanto, à luz do direito oficial brasileiro, as relações desse tipo estabelecidas no interior das favelas são ilegais ou juridicamente nulas, uma vez que dizem respeito a transações sobre terrenos ilegalmente ocupados e a construções duplamente clandestinas. Dentro da comunidade, contudo, as relações são legais e como tal são vividas pelos que nelas participam; a intervenção dos moradores neste domínio visa constituir como que um Ersatz da proteção jurídica oficial de que carecem ${ }^{68}$.
\end{abstract}

Aqui, as práticas sociais e jurídicas, tais como compra e venda de imóveis,

\footnotetext{
64 Loc. cit.

${ }^{65}$ BORTOLOZZI JUNIOR, Flávio. Pluralismo jurídico e o paradigma do direito moderno: breves apontamentos. Cadernos da Escola de Direito e Relações Internacionais, n. 12, 2010, p. 27.

66 FELISMINO, Lia Cordeiro. Pluralismo jurídico: um diálogo entre os pensamentos emancipatórios de Boaventura de Sousa Santos e Antônio Carlos Wolkmer. Anais do XIX Encontro Nacional do CONPEDI. Tema: Direitos Fundamentais e Transdisciplinaridade. Fortaleza, 9, 10, 11 e 12 de junho de 2010, p. 8486.

${ }^{67}$ Loc. cit.

${ }^{68}$ SANTOS, Boaventura de Sousa. O discurso e o poder. Ensaios sobre a sociologia retórica jurídica. Porto Alegre: SAFE, 1988, p. 14.
} 
arrendamento de terrenos etc., eram consideradas ilegais pelo direito estatal, já que não eram originários de títulos "legais" de posse/propriedade. Isso não inibia, contudo, a que, no interior desta comunidade, admitisse-se uma forma de dinâmica social e uma normatividade paralela a do Estado, onde a associação de moradores desempenhava papel de fórum jurídico e desenvolvia práticas e discursos jurídicos ${ }^{69}$.

Por não ser oficial, o direito de Pasárgada tem a sua validade restrita ao interior da comunidade. É caracterizado por ter um discurso jurídico informal e uma linguagem comum, diferentemente do formalismo jurídico, de linguajar rebuscado, imposto pelo direito positivo estatal $^{70}$.

Nessa comunidade, as decisões, antes de se constituírem na aplicação direta de fatos às normas, eram produtos da aplicação, gradual, provisória, irreversível, cuja carga normativa, cuja fundamentação fática era dominada pela argumentação respaldada em situações concretas, no intuito de se obter uma decisão que fosse aceita pelas partes e pelo auditório em causa (composto, normalmente, por acompanhantes das partes). Além disso, no direito de Pasárgada, as decisões assumiam, via de regra, formas de mediação ou negociação, diferentemente do que ocorre no domínio do direito estatal, em que há a polarização entre vencedor e vencido ${ }^{71}$.

Outra característica do direito de pasárgada trazida por Boaventura reside em que, no direito de Pasárgada, o discurso jurídico não é legalista, e se projetava sobre um pensamento essencialmente comum e quotidiano, por meio de uma linguagem também comum ${ }^{72}$.

As distinções entre forma e conteúdo eram pouco rígidas, sendo que os formalismos processuais, em vez de se constituírem como o limite do discurso jurídico, como no caso do direito positivo estatal, eram utilizados como argumentos. O grau de institucionalização era muito pequeno, e não necessitava de especialização profissional ${ }^{73}$.

Em relação ao poder dos instrumentos de coerção ao serviço da produção jurídica, a diferença é enorme. O Direito Estatal dispõe um amplo e poderoso aparato coercitivo,

\footnotetext{
${ }^{69}$ FELISMINO, Lia Cordeiro. Pluralismo jurídico: um diálogo entre os pensamentos emancipatórios de Boaventura de Sousa Santos e Antônio Carlos Wolkmer. Anais do XIX Encontro Nacional do CONPEDI. Tema: Direitos Fundamentais e Transdisciplinaridade. Fortaleza, 9, 10, 11 e 12 de junho de 2010, p. 8487.

${ }^{70}$ Loc. cit.

${ }^{71}$ Loc. cit.

${ }^{72}$ Loc. cit.

${ }^{73}$ Loc. cit.
} 
detentor do monopólio da violência legítima, como as forças policiais, paramilitares e mesmo forças $\operatorname{armadas}^{74}$.

O Direito de Pasárgada, ao contrário, dispunha de instrumentos de coerção muito incipientes e de fato quase inexistentes. A associação participava na organização de formas coletiva de coerção contra um vizinho transgressor que não se deixava persuadir pela retórica jurídica no sentido da reposição da legalidade. Era notória "uma circulação retórica que tende a subverter qualquer divisão rígida do trabalho jurídico, o que, por esta via, potencia a proximidade entre o agente privilegiado do discurso (o presidente) os demais participantes e o auditório"75.

A característica fundamental do sistema jurídica de Pasárgada é que este se reveste de um discurso tópico-retórico, em oposição ao discurso lógico-sistemático do Direito Estatal ${ }^{76}$.

Segundo a concepção tópico-retórico, o discurso jurídico tem uma natureza argumentativa, visando uma deliberação dominada pela lógica do razoável em face do circunstancialismo concreto do problema, em caso algum redutível à dedução lógica e necessária a partir de enunciados normativos gerais. ${ }^{77}$

Percebe-se ainda no que refere à diferenciação entre o direito de Pasárgada e o direito Estatal (denominado, pelos moradores, de direito do asfalto), que o direito de Pasárgada, quanto aos instrumentos de coerção, somente os possui de maneira escassa, sendo que os principais instrumentos de coerção acabam sendo a ameaça e o discurso da violência, ao contrário do estatal, que dispõe de um amplo e institucionalizado aparato de coerção ${ }^{78}$.

Entretanto, apesar da existência de um direito paralelo ao direito estatal, e das diferenças entre ambos, percebe-se uma constante interação entre esses ordenamentos jurídicos. Frequentemente, o direito de Pasárgada recorre ao discurso oficial, mesmo que apenas como argumento, seja para se legitimar, seja para construir um ambiente de maior oficialidade e justificar a imposição de algumas decisões, por meio da ameaça da aplicação do

\footnotetext{
${ }^{74}$ BORTOLOZZI JUNIOR, Flávio. Pluralismo jurídico e o paradigma do direito moderno: breves apontamentos. Cadernos da Escola de Direito e Relações Internacionais, n. 12, 2010, p. 28.

75 SANTOS. Boaventura de Sousa. O discurso e o Poder: ensaio sobre a sociologia da retória jurídica. Porto Alegre: Fabris, 1988, p. 46.

${ }^{76}$ BORTOLOZZI JUNIOR, Flávio. Op. cit., p. 27.

77 SANTOS. Boaventura de Sousa. Op. cit., p. 7.

78 FELISMINO, Lia Cordeiro. Pluralismo jurídico: um diálogo entre os pensamentos emancipatórios de Boaventura de Sousa Santos e Antônio Carlos Wolkmer. Anais do XIX Encontro Nacional do CONPEDI. Tema: Direitos Fundamentais e Transdisciplinaridade. Fortaleza, 9, 10, 11 e 12 de junho de 2010, p. 8487-8488.
} 
direito estatal, caso haja o descumprimento das regras de conduta estabelecidas pela comunidade $^{79}$.

Portanto, o direito de Pasárgada é um direito paralelo não oficial, cobrindo uma interação jurídica muito intensa à margem do sistema jurídico estatal (o direito do asfalto, como lhe chamam os moradores das favelas, por ser o direito que vigora apenas nas zonas urbanizadas e, portanto, com pavimentos asfaltados) e tinha como objetivo "maximizar o desenvolvimento interno da comunidade e garantir a segurança e a ordem nas relações sociais entre os habitantes" ${ }^{\$ 0}$. Obviamente, o direito de Pasárgada é apenas válido no seio da comunidade e a sua estrutura normativa assenta na inversão da norma básica (Grundnorm) da propriedade, por meio da qual o estatuto jurídico da terra de Pasárgada é consequentemente invertido $^{81}$ : a ocupação ilegal (segundo o direito do asfalto) transforma-se em posse e propriedade legais (segundo o direito de Pasárgada)". ${ }^{82}$ Possuindo características informais, os requisitos e formais processuais mantêm caráter exclusivamente instrumental, apenas sendo usados para contribuir à decisão justa da lide.

Conforme Souza Santos, "Esta falta de uniformidade, que pode surpreender ou mesmo escandalizar quem a veja com os olhos etnocêntricos do direito oficial, não é, no entanto, caótica" ${ }^{\$ 3}$. Aliado à esta característica, a linguagem do discurso pasargadiano é comum e acessível àqueles que utilizam-na.

No que tange à institucionalização e à coerção, pode-se aqui apontar mais diferenças entre o Direito oficial e o sistema jurídico de Pasárgada. O Direito Estatal apresenta alto grau de institucionalização, sendo a função jurídica autônoma às demais funções sociais, bem como possui alto grau de especialização. O Direito de Pasárgada, por sua vez, apresenta um

\footnotetext{
${ }^{79}$ Ibid., p. 8488 .

${ }^{80}$ SANTOS. Boaventura de Sousa. O discurso e o poder. Ensaios sobre a sociologia retórica jurídica. Porto Alegre: SAFE, 1988, p. 11.

${ }^{81}$ Conforme sinaliza Boaventura de Souza Santos, um parcela importante da intervenção da associação, no microcosmo social constituído pela favela, dá-se no campo da administração das relações entre seus próprios moradores, repartindo-se basicamente em duas áreas: 1) ratificação das relações jurídicas e 2) prevenção e resolução de litígios (Loc. cit.).

82 Ibid., p. 14.

${ }^{83}$ Ibid., p. 31. Souza Santos complementa: “A sistematização da atuação derivam não só da lógica normativa constitucional que subjaz à filosofia política do estado liberal como, mais imediatamente, do vasto arsenal do formalismo jurídico em geral e do formalismo processual em especial e ainda da profissionalização do contexto em que estes são accionados". Ibid., p. 52.
} 
grau de institucionalização baixo; a associação de moradores desempenha diversas outras funções além da jurídica ${ }^{84}$.

\subsection{Do direito de pasárgada à manifestação legal do pluralismo no Brasil: o exemplo dos juizados especiais civil}

Dentre as muitas contribuições doutrinárias para a teoria do pluralismo jurídico, encontra-se a proposta de "pluralismo jurídico comunitário-participativo" apresentada por Antonio Carlos Wolkmer. Tal proposta consagra a legitimidade dos sujeitos emergentes na criação e efetivação dos "novos direitos" ${ }^{\text {" }}$, buscando a instauração de um pluralismo jurídico de cunho integrador, que promova e estimule a participação do segmentos populares e dos novos sujeitos coletivos, satisfazendo efetivamente suas necessidades ${ }^{86}$.

A proposta de Wolkmer busca também a concretização de um projeto jurídico fruto das "práticas sociais insurgentes, motivada para a satisfação justa de necessidades essenciais", bem como "contempla também uma ampla gama de manifestações de normatividade paralela, institucionalizadas ou não, de cunho legislativo ou jurisdicional, 'dentro' e 'fora' do sistema estatal positivo" $" 87$.

Nesse contexto, no Brasil, criou-se os Juizados Especiais de Pequenas Causas, por meio da Lei n. ${ }^{\circ}$ 7.244, de 7 de Novembro de 1984, que foram precedidos pelos Juizados Informais de Conciliação em diversas cidades do Estado de São Paulo. O êxito da iniciativa fica claramente demonstrado pelo número de juizados criados e instalados em 1999: 759 Juizados em todo o Brasil, onde até essa data desempenhavam funções 1.170 juízes. $^{88}$

\footnotetext{
${ }^{84}$ BORTOLOZZI JUNIOR, Flávio. Pluralismo jurídico e o paradigma do direito moderno: breves apontamentos. Cadernos da Escola de Direito e Relações Internacionais, n. 12, 2010, p. 28.

${ }^{85}$ Conforme esclarece o autor: "Ainda que os chamados direitos 'novos' nem sempre sejam inteiramente 'novos' na verdade, por vezes, o 'novo' é o modo de obtenção de direitos que não passam mais pelas vias tradicionais legislativa e judicial -, mas provêm de um processo de lutas e conquistas das identidades coletivas para o reconhecimento pelo Estado. Assim, a designação de novos direitos refere-se à afirmação e materialização de necessidades individuais (pessoais) ou coletivas (sociais) que emergem informalmente em toda e qualquer organização social, não estando necessariamente previstas ou contidas na legislação estatal positiva" (Antonio Carlos Wolkmer, Pluralismo Jurídico: fundamentos de uma nova cultura no direito, 3. ed., São Paulo: Alfa Omega, 2001).

${ }^{86}$ BORTOLOZZI JUNIOR, Flávio. Pluralismo jurídico e o paradigma do direito moderno: breves apontamentos. Cadernos da Escola de Direito e Relações Internacionais, n. 12, 2010, p. 29.

87 WOLKMER, Antonio Carlos. Pluralismo jurídico: novo paradigma de legitimação. Disponível em < http://www.mundojuridico.adv.br/sis_artigos/artigos.asp?codigo=646 >. Acesso em 25 de fev. de 2013.

${ }^{88}$ FAISTING, André Luiz. O dilema da dupla institucionalização do poder judiciário: o caso do juizado especial
} 
Refira-se que a designação de Juizados de Pequenas Causas foi alterada por meio da Lei n. ${ }^{\circ}$ 9.099, de 26 de Setembro de 1995, devido ao fato de a Constituição brasileira se referir a causas cíveis de menor complexidade e não a causas de menor valor econômico, propondo que se designassem antes de Juizado de Causas Cíveis de Menor Complexidade e de Juizado Criminal de Infrações de Menor Potencial Ofensivo. Esta lei criou então os Juizados Especiais Cíveis e Criminais que são "órgão da Justiça Ordinária" a criar "pela União, no Distrito Federal e nos Territórios, e pelos Estados, para conciliação, processo, julgamento e execução, nas causas da sua competência". Embora partisse dos mesmos fundamentos da lei anterior, veio acrescentar algumas novidades, nomeadamente o alargamento do valor das ações para 40 salários mínimos, a obrigatoriedade da presença de advogado nas causas entre 20 e 40 salários mínimos, o alargamento das suas competências à área criminal e a obrigatoriedade da existência destes órgãos nos Estados.

Conforme referido por Grinover, esta lei produziu uma verdadeira revolução no sistema processual penal brasileiro ao não se limitar a importar soluções de outros sistemas jurídicos, mas instituindo um sistema próprio de justiça penal consensual ${ }^{89}$. De acordo com a lei, os juizados devem pautar a sua atuação pela oralidade, simplicidade, informalidade, economia processual e celeridade, tentando, sempre que possível, a conciliação ou a transação.

Os serviços de cartório podem ser prestados e as audiências realizadas fora da sede da Comarca, em bairros ou em cidades pertencentes à Comarca, ocupando prédios públicos. A descentralização da justiça nos bairros, com a criação de tribunais especiais para o julgamento de causas de diminuta complexidade e com serviços de assistência judiciária, implica que os juizados sejam polos de informação de direitos, pondo cobro à desinformação jurídica e facilitando o acesso de classes menos favorecidas à justiça. O objetivo dos Juizados Especiais é a aproximação da justiça aos cidadãos. Para o efeito, alguns dos Juizados funcionam em centros comerciais e até em autocarros: os Juizados Itinerantes, nos quais funciona uma sala de audiências e duas salas de conciliação. Para Ovídio Batista:

Estas justiças especiais, para as causas de reduzida expressão econômica, foram
inspiradas nas experiências de outros povos, particularmente nas Small Claims
Courts, existentes nos Estados Unidos da América, foram sugeridas pela Lei Federal,
cabendo aos Estados cria-las ou não, segundo seus próprios critérios de
conveniência, numa tentativa de introduzir no Brasil uma forma de justiça
alternativa, despida do formalismo próprio das cortes de justiça ordinária, e de

de pequenas causas. In: SADEK, M.T. (Org.). O sistema de justiça. São Paulo: Editora Sumaré, 1999, p. 45.

${ }^{89}$ GRINOVER, Ada Pellegrini et. al. Juizados Especiais Criminais - Comentários à Lei 9.099 de 26.09.95. São Paulo: Revista dos Tribunais, 1996, p. 2. 
índole mais participativa e menos profissionalizada e burocrática, através da convocação de juízes não integrantes dos quadros do Poder Judiciário, e com o nítido sentido de justiça conciliadora, menos técnica e mais democrática. ${ }^{90}$

O legislador brasileiro incentivou a participação popular nos juizados especiais, quer na função de conciliação, quer na de juiz leigo, com competência para dirigir a instrução e julgamento, sob a supervisão do juiz "togado" (magistrado judicial), e para proferir decisão, posteriormente homologada pelo juiz togado. Os juízes leigos podem, ainda, atuar como árbitros com poderes idênticos aos do juiz togado, podendo decidir por equidade. Tal fundamentação vem da percepção de que o Direito já não é mais decorrente unicamente do Estado, mas também da sociedade, que busca se autorregulamentar, por meio de novos sujeitos emergentes.

\section{Conforme Grossi:}

[...] se assiste a 'atores modificados protagonistas do processo jurídico', a 'diferentes modalidades de produção e de funcionamento das regras jurídicas', a uma crescente privatização da produção jurídica: vitais centros monopoiéticos (ou seja, produtores de regras jurídicas prontamente observadas pelos indivíduos) já estão inseridos em núcleos sociais, econômicos e culturais muito distantes dos Estados ${ }^{91}$.

A concepção do pluralismo jurídico busca aproximar a sociedade do Direito, o direito concreto e efetivo, social, democrático, participativo e, acima de tudo, justo; que respeita as minorias e a multiculturalidade, e não daquele direito-lei, individualista, que é ineficaz e que não propaga a Justiça ${ }^{92}$.

No entanto, a doutrina pluralista não se pretende absoluta, única e dogmatizada, como o faz o monismo estatal. Sua legitimação é buscada nas expressões da sociedade e apenas por meio da própria sociedade pode se concretizar. Embora não se oponha à figura do Estado, não o concebe como absoluto e incondicional detentor da criação de normas jurídicas. ${ }^{93}$ Menciona-se novamente as palavras de Paolo Grossi:

É claro que o Estado não pode abdicar da fixação de linhas fundamentais, mas também é claro que se impõe uma deslegificação, abandonando a desconfiança iluminista do social e realizando um autêntico pluralismo jurídico, onde os indivíduos sejam os protagonistas ativos da organização jurídica do mesmo modo

\footnotetext{
${ }^{90}$ SILVA, Ovídio A. Baptista da. Curso de Processo Civil. v. 1. Processo de Conhecimento. 6. ed. rev. e atual. São Paulo: Revista dos Tribunais, 2002, p. 55-56.

91 GROSSI, Paolo. Mitologias jurídicas da modernidade. Tradução de Arno Dal Ri Junior. Florianópolis: Fundação Boiteux, 2004, p. 99-100.

${ }^{92}$ Loc. cit.

${ }^{93}$ BORTOLOZZI JUNIOR, Flávio. Pluralismo jurídico e o paradigma do direito moderno: breves apontamentos. Cadernos da Escola de Direito e Relações Internacionais, n. 12, 2010, p. 30.
} 
que acontece nas transformações sociais. Somente dessa forma será possível preencher o fosso que atualmente constatamos com amargura ${ }^{94}$

Portanto, não se trata, aqui, da falência do Estado, mas sim de uma profunda transformação. Este é necessário para a paz social, no entanto, não pode presumir-se único e onipotente na função de criação de normas jurídicas, mesmo porque está distante das necessidades sociais e de sua dinâmica. A emergência de novos atores no cenário da confecção jurídica já é factual e deve o jurista desamarrar-se de antigos dogmas individualistas, que já não mais condizem com a realidade e com a necessidade da sociedade, e buscar a consolidação da Justiça Social como forma de evolução jurídica. ${ }^{95}$

\section{CONSIDERAÇÕES FINAIS}

Como afirmado na introdução, este texto procurou analisar de forma paralela o pluralismo jurídico em Moçambique e no Brasil, fazendo ênfase ao estudo feito por Boaventura de Sousa Santos, que parte de duas concepções por ele apelidadas (palimpsesto ${ }^{96}$ político e jurídico em moçambique e direito de pasárgada no Brasil).

O pluralismo jurídico Moçambicano não pode ser analisado apenas a partir do que o colonialismo reconheceu ou do que está previsto na legislação. A realidade é complexa e imprevisível. As práticas são altamente diversificadas e os diferentes direitos tendem a ser usados de forma interligada, de acordo com as estratégias das instâncias que resolvem conflitos e dos próprios litigantes. Ademais, o pluralismo jurídico é a oposição ao formalismo jurídico do positivismo posto pela sociedade burguesa, é contra o monismo jurídico estatal, sendo o surgimento e uso de um direito paralelo ao direito estatal que tem eficácia simultaneamente em uma mesma sociedade, o que faz ocorrer que o uso de um ofusca o outro. O direito é projeção normativa que instrumentaliza os princípios ideológicos, tendo como umas das bases a certeza e a segurança, sendo formas de controle do poder de um determinado grupo social.

Já no Brasil, o direito de Pasárgada recorre, frequentemente, ao direito oficial, ainda que

\footnotetext{
${ }^{94}$ GROSSI, Paolo. Op. cit., 145-146.

${ }^{95}$ BORTOLOZZI JUNIOR, Flávio. Pluralismo jurídico e o paradigma do direito moderno: breves apontamentos. Cadernos da Escola de Direito e Relações Internacionais, n. 12, 2010, p. 30.

96 Boaventura de Sousa Santos, serve-se de uma metáfora para pretende mostrar como as diferentes culturas políticas e jurídicas que perpassaram o Estado Moçambicano ao longo da sua história continuam a cruzar-se na realidade política e judiciária moçambicana: o palimpsesto de políticas e culturas jurídicas. Um palimpsesto é um pergaminho ou outro material sobre o qual se escreve a segunda vez, mas cuja primeira escrita não desaparece totalmente.
} 
somente a título argumentativo, seja para se legitimar, seja para construir um ambiente de maior oficialidade, ou seja, ainda, para impor as suas decisões, por meio da ameaça da aplicação do direito estatal, caso haja o descumprimento das regras de conduta estabelecidas pela comunidade.

Apesar de essa manifestação normativa ser caracterizada por pluralismo jurídico, esse fenômeno vem se reconfigurando em uma nova forma de expressão jurídica, identificada com a mobilização de diversos atores sociais em torno de resistências e de lutas contra as práticas desiguais e excludentes oriundas do neoliberalismo e com a reafirmação dos sistemas jurídicos não estatais. Nesse ponto específico, encontra-se o marco de conexão do presente estudo de caso com o pluralismo jurídico, se não na expressão de novas fontes jurídicas afirmadas, mas sim em uma forma embriônica de busca por justiça alternativa. Um exemplo concreto da busca por uma justiça alternativa é a disseminação dos Juizados Especiais, criados com competência para o processo e julgamento de causas de reduzido valor econômico. Primeiro, com a promulgação da Lei Federal n. 7.244, de 7 de novembro de 1984, que regulamentava a criação e funcionamento dos Juizados Especiais de Pequenas Causas, depois tal lei foi revogada com a promulgação da Lei 9.099, de 26 de setembro de 1995, que instituiu os Juizados Especiais, tanto no âmbito da jurisdição civil quanto no da jurisdição criminal, com competência para conciliação e julgamento, no campo da jurisdição civil, das causas cujo valor não exceda sessenta vezes o salário mínimo.

\section{REFERÊNCIAS}

AFRICA DO SUL. Constituição da República da África do Sul. 1996. Disponível em: <http://www.constitutionalcourt.org.za/site/constitution/english-web/ch2.html>. Acesso em: 20 nov. 2013.

- Council of Traditional Leaders Bill de 1996. Disponível em: <www.gov.za/documents/download.php?f=71927>. Acesso em: 20 nov.2013.

Council of Traditional Leaders Act de 1997. Disponível em: < www.parliament.gov.za/live/.../221615_1.pdf>. Acesso em: 20 nov. 2013.

ALMEIDA, Pedro Ramos de. História do Colonialismo Português em África. Cronologia Século XX. Imprensa Universitária. n. 5. Lisboa: Editorial Estampa, 1979. 
ARAÚJO, Sara. O Estado moçambicano e as justiças comunitárias: Uma história dinâmica de imposições e respostas locais diferenciadas. 7. ${ }^{\circ}$ Congresso Ibérico de Estudos Africanos, 2010, p. 1-17. Disponível em: http://www.ces.uc.pt/myces/UserFiles/encontros/1097_CIEA7_29_ARA\%DAJO_O\%20Estad o\%20mo\%E7ambicano $\% 20 \mathrm{e} \% 20$ as $\% 20 \mathrm{justi} \% \mathrm{E} 7 \mathrm{as} \% 20$ comunit $\%$ E1rias.pdf $>$. Acesso em 05 de mar. de 2013.

ARAÚJO, Sara; JOSÉ, André. Pluralismo jurídico, legitimidade e acesso à justiça. Instâncias comunitárias de resolução de conflitos no Bairro de Inhagoia «B» - Maputo. Oficina do CES. n. 284. Coimbra: CES, 2007.

ARNAUD, André-Jean Arnaud; FARINÃS DULCE, Maria José. Introdução à analise sociológica dos sistemas jurídicos. Rio de Janeiro: Renovar, 2000.

BEZERRA, Paulo Cesar Santos. Acesso à justiça: um problema ético-social no plano da realização do direito. Rio de Janeiro: Renovar, 2002.

BORTOLOZZI JUNIOR, Flávio. Pluralismo jurídico e o paradigma do direito moderno: breves apontamentos. Cadernos da Escola de Direito e Relações Internacionais, n. 12, 2010, p. 21-31.

BRASIL. Constituição da República Federativa do Brasil de 1988. São Paulo: Atlas, 2001.

Lei n. ${ }^{\circ}$ 7.244, de 7 de Novembro de 1998, que cria os Juizados Especiais de Pequenas Causas.

CANOTILHO, José Joaquim Gomes. Direito Constitucional e Teoria da Constituição. 6. ed. Coimbra, Portugal: Almedina, 2002.

CARVALHO, Lucas Borges de. Caminhos (e descaminhos) do pluralismo jurídico no Brasil. In: WOLKMER, Antonio Carlos; VERNAS NETO, Francisco Q.; LIXA, Ivone M. (Orgs.). Pluralismo jurídico: os novos caminhos da contemporaneidade. São Paulo: Saraiva, 2010, p. 13-36.

COLÔMBIA. Constituição de 1991. Bogotá: [s. n.], 1991.

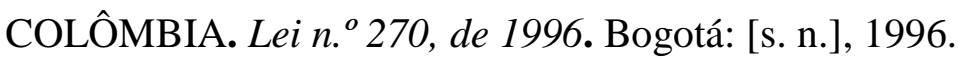


FAISTING, André Luiz. O dilema da dupla institucionalização do poder judiciário: o caso do juizado especial de pequenas causas. In: SADEK, M.T. (Org.). O sistema de justiça. São Paulo: Editora Sumaré, 1999.

FELISMINO, Lia Cordeiro. Pluralismo jurídico: um diálogo entre os pensamentos emancipatórios de Boaventura de Sousa Santos e Antônio Carlos Wolkmer. Anais do XIX Encontro Nacional do CONPEDI. Tema: Direitos Fundamentais e Transdisciplinaridade. Fortaleza, 9, 10, 11 e 12 de junho de 2010, p. 8480-8493.

FONSECA, Jorge Carlos de Almeida (Coord.). Estudo sobre o estado da Justiça em Cabo Verde. Praia: Gabinete do Ministro da Justiça, Governo de Cabo Verde, 2002.

GRIFFITHS, John. What is Legal Pluralism? Journal of Legal Pluralism and Unofficial Law, n. 24, 1986, p. 1-55.

GRINOVER, Ada Pellegrini et. al. Juizados Especiais Criminais - Comentários à Lei 9.099 de 26.09.95. São Paulo: Revista dos Tribunais, 1996.

GROSSI, Paolo. Mitologias jurídicas da modernidade. Tradução de Arno Dal Ri Junior. Florianópolis: Fundação Boiteux, 2004.

KELSEN, Hans. Teoria Geral do Direito e do Estado. Trad. Luis Carlos Borges. 3. ed. São Paulo: Martins Fontes, 1998.

MAR, Eli. J. E. Exploração Portuguesa em Moçambique 1500 - 1973. Esboço Histórico. Kastrup: African Studies, 1975. 2 v.

MEDRADO, Luiz Flávio Matos. Do monismo ao pluralismo jurídico. JurisWay. Disponível em: < http://www.jurisway.org.br/v2/dhall.asp?Id_dh=4280 >. Acesso em 05 de mar. de 2013.

MERRY, Sally Engle. Legal pluralism. Law \& Society Review, v. 22, n. 5, 1988, pp. 869-896.

MOÇAMBIQUE. Constituição da República de Moçambique de 2004. Disponível em: <http://www.mozambique.mz/ pdf constituição 2004>. Acesso em 26 de dez. 2012.

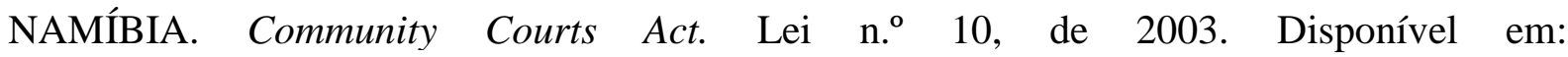
<www.parliament.gov.na/acts/acts.php?list_id=50 >. Acesso em 20 nov. 2013. 
NOËL ROTH, André. O Direito em Crise: Fim do Estado Moderno? In: FARIA, José Eduardo (Org.). Direito e Globalização Econômica: Implicações e Perspectiva. São Paulo: Malheiros.

PIRES, Caio José Leitão; GOMES, Raíza Feitosa. O pluralismo jurídico e a real participação da sociedade nas questões jurídicas - uma análise de caso. Âmbito Jurídico. Rio Grande, XIV, n. 91, ago. 2011. Disponível em: <http://www.ambitojuridico.com.br/site/index.php?n_link=revista_artigos_leitura\&artigo_id= 9998>. Acesso em mar. 2013.

POMBAL, António. O Poder executivo na experiência Moçambicana. In: Controle Social do Poder Político em Moçambique Divisão de Poderes. Nampula: Centro de Pesquisa Konrad Adenauer, 2003.

PORTUGAL. Constituição (1976). Constituição da República Portuguesa. Atualizada de acordo com a Lei Constitucional $n^{\circ}$ 1/2004, de 24 de julho de 2004. Coimbra: Almedina, 2004.

RANDEIRA. Shalino. Pluralismo Jurídico, soberania fraturada e direitos de cidadania diferenciados: instituições internacionais, movimentos sociais e Estado pós-colonial na Índia. Trad. de Ana Cláudia Jorge. In: SANTOS, Boaventura de Sousa (Org). Reconhecer para Libertar: os caminhos do cosmopolitismo multicultural. Rio de Janeiro: Civilização Brasileira, 2003.

SANTOS, Boaventura de Sousa. $O$ discurso e o poder. Ensaios sobre a sociologia retórica jurídica. Porto Alegre: SAFE, 1988.

. O Estado heterogéneo e o pluralismo jurídico. In: SANTOS, Boaventura de Sousa; TRINDADE, João Carlos (Orgs.). Conflito e Transformação Social: Uma Paisagem das Justiças em Moçambique. v. I. Porto: Afrontamento, 2003, pp. 47-128.

Para um novo senso comum: a ciência, o Direito e a política na transição paradigmática. 3. ed. São Paulo: Cortez Editora, 2001.

. Pela Mão de Alice: O Social e o Político na pós-modernidade. São Paulo, ed.

Cortez, 1997.

SERRA, Carlos Manuel. Estado, Pluralismo Jurídico e Estado, Pluralismo Jurídico e Pluralismo Jurídico Recursos Naturais. Disponível em: <http://www.cfjj.org.mz/img/pdf/microsoft_word_-_trabalho_pluralismo_juridico_1_.pdf $>$. 
Acesso em 25 de fev. de 2013.

SILVA, Cristina Nogueira da. Codificação de Usos e Costumes na Doutrina Colonial. Quaderni Fiorentini per la Storia del Pensiero Giuridico Moderno, n. 33-34, t. II, 2004-2005, p. 899-921.

SILVA, Ovídio Araújo Baptista da. Curso de processo civil: processo de conhecimento. v. 1. 6. ed. rev. e atual. São Paulo: Revista dos Tribunais, 2002.

TAMANAHA, Brian. Understanding Legal Pluralism: Past to Present, Local to Global. Sidney Law Review, v. 30, n. 3, September 2008, p. 375-411.

TRINDADE, João Carlos. Rupturas e continuidades nos processos políticos e jurídicos In: SANTOS, Boaventura de Sousa; TRINDADE, João Carlos (Orgs.). Conflito e Transformação Social: Uma Paisagem das Justiças em Moçambique. v. I. Porto: Afrontamento, 2003, p. $97-$ 128.

UGANDA. Ministry of Local Government of the Republic of Uganda (2003). Local Councils Administration of Justice. Guides for Local Council Courts. Disponível em: <http://www.molg.go.ug/docs/Local CourtsGuide.pdf>. Acesso em 20 nov. 2013.

VASCONCELOS, Arnaldo. Teoria da Norma Jurídica. 6. ed. São Paulo: Malheiros, 2006.

WOLKMER, Antonio Carlos. Pluralismo Jurídico: fundamentos de uma nova cultura no direito. 3. ed. São Paulo: Alfa Omega, 2001.

. Pluralismo jurídico: novo paradigma de legitimação. Disponível em < http://www.mundojuridico.adv.br/sis_artigos/artigos.asp?codigo=646 >. Acesso em 25 de fev. de 2013.

Submissão: 18/09/2013

Aceito para Publicação: 13/12/2013 